\title{
NOG EEN PAAR OPMERKINGEN OVER HET WOORD „KABAYAN".
}

DOOR

\author{
C. C. BERG.
}

In deel 85, p. 469 sqq., van deze Bijdragen wees ik, vooral in verband met een beschouwing, die Mevr. Dr. Coster-Wijsman aan het woord kabayan gewijd had, op twee mogelijkheden ter verklaring van dit woord, waarop, voor zoover ik wist, nog niet, of althans nog niet uitdrukkelijk ${ }^{1}$ ), de aandacht gevestigd was geworden. Mijn opzet was om op eenige mogelijkheden te wijzen en den weg voor andere mogelijkheden geheel vrij te laten; ook toen ik bij een volgende gelegenheid ${ }^{2}$ ) op de verklaring van het woord kabayan terugkwam, heb ik, hoewel ik voor een mijner hypothesen nieuwen steun meende gevonden te hebben, er voor gezorgd mij zoo voorzichtig mogelijk uit te drukken en niet den indruk te wekken, als zou ik van de juistheid van een der opvattingen overtuigd zijn geraakt. Vindt iemand een alleszins bevredigende verklaring, dan zal ik de eerste zijn om te erkennen, dat daarmee mijn vroegere hypothesen haar waarde verloren hebben. Het onlangs verschenen ${ }^{3}$ ) nieuwe opstel van Mevr. Coster-Wijsman is een gereede aanleiding om mij af te vragen, of wellicht het oogenblik voor zulk een erkenning thans gekomen is.

Sinds het verschijnen van deel 85 der Bijdragen heb ik n.1. met twee nieuwe opvattingen kennis gemaakt: met een gissing van Dr. D. van Hinloopen Labberton, die kabayan met het welbekende woord kabeh, ouder Javaansch ook kabaih, ,alle”, ,allen”, ,alles”, in verband wil brengen, zooals hij mij mededeelde in een brief dd. Naarden, 1 November $1929^{4}$ ), en met een opvatting, dat kabayan af te leiden is van het Sanskrt woord wayas of een daarop teruggaand Oud-Javaansch woord; deze laatste opvatting hebben, klaarblijkelijk onafhankelijk van elkaar, twee schrijvers geponeerd, niet als gissing, doch als eenige mogelijkheid: de heer W. J. de Wilde in No. 11, dd. 1 Februari 1930, p. 127-128, van het te Bandoeng 
verschijnende „O.S.V.I.A.-Maandblad” en Dr. W. Aichele in een opstel „Altjavanische Berufsbezeichnungen” met een naschrift „Zur Nenek Kĕbayan” in het „Zeitschrift für Eingeborenensprachen”, Band XXI, 1931, p. 230-237 en p. 2475), terwij1 Dr. J. Gonda onlangs in deze Bijdragen (deel 90, p. 163) terloops opmerkte, dat hij voor zich eveneens tot deze opvatting gekomen was.

Hieronder wil ik in het bijzonder de door Dr. Aichele gegeven verklaring van het woord kabayan critisch bespreken; het overige deel van zijn veelszins belangrijke verhandeling laat ik gaarne in zijn waarde. Uiteraard brengt het vergelijken van het voor en tegen van eenige verklaringen van een duister woord met zich mee, dat men in détails moet afdalen, die op zichzelf wellicht van ondergeschikt belang zijn. Bij het openleggen der Oud-Javaansche litteratuur zullen echter het etymologiseeren van woorden en het interpreteeren van teksten voorloopig nog wel zulk een belangrijke rol blijven spelen, dat het zijn nut kan hebben af en toe eens duidelijk in het licht te stellen, hoe moeilijk het in het algemeen is in het huidige stadium van onze kennis van het Oud-Javaansch juist op die beide gebieden iets met zekerheid te zeggen; en de beste manier om dat in het licht te stellen is om eens een geval aan alle kanten te bekijken. Het rijk gedocumenteerde artikel van Dr. Aichele, waarvoor ik ondanks alle meeningsverschil oprechte waardeering koester, leent zich uitstekend tot een uitvoerige behandeling, een behandeling, waarmee de bespreking van de these van den heer de Wilde zonder bezwaar kan samenvallen. Ik heb gemeend de meening van Dr. van Hinloopen Labberton het best te kunnen bespreken in de noot zelf (noot 4, p. 620), waarin ik haar tot uiting heb laten komen; wellicht vindt hij in mijn opmerkingen aanleiding zijn opvatting nog eens wat uitvoeriger toe te lichten.

Dr. Aichele bespreekt in zijn opstel zoowel de beteekenis van kabayan als de vorming en de herkomst van het woord. Ten aanzien van de herkomst merkt hij op, dat het teruggaat op Sanskrt wayas via baya, een hypothetischen nevenvorm, in den Archipel ontstaan, van het wayah, dat o.a. nog in het huidige Javaansch voorkomt; wat de vorming betreft, hebben wij, volgens A., hier te maken met een excessivus, een vorm bestaande uit grondwoord plus praefix ka- plus suffix -ěn, waarvan echter de pěpět met de slotvocaal van het grondwoord is samengesmolten, en overeenkomende met het Nieuw-Javaansche kĕtuwan; ten aanzien van het eerste punt ten 
slotte is A. van meening, ,dasz die Bedeutung des Wortes kabayan „sehr alt, ältester" sein m u s s" (spatiëering van mij, B.).

Laat ons, als A. zelf, beginnen met de vraag naar de beteekenis. Blijkens de vertalingen, die A. zelf geeft op p. 231 sqq. van zijn opstel, beperkt hij de beteekenis niet tot ,zeer oud” en ,oudst”, doch acht hij ook ,oud" en ,te oud" aequivalent aan het woord in kwestie. Ten bewijze van de juistheid van zijn stelling beroept hij zich op drie plaatsen in het Oud-Javaansche Wirātaparwa, waar kabayan volgens hem in ieder geval een dier beteekenissen heeft, verder op één plaăts, waar het een van die beteekenissen kan hebben. en ten slotte op één plaats, waar het bij wijze van conjectuur een dier beteekenissen toegekend zou kunnen worden. Het komt mij echter voor, dat bij een nadere beschouwing de bewijskracht der aangehaalde plaatsen onvoldoende blijkt. Gesteld immers al, dat wij met de vertalingen van $\mathrm{A}$. accoord gingen, dan waren wij het er nog slechts over eens, dat op de aangehaalde plaatsen kabayan met „oud" weergegeven kan worden. Echter moeten wij, om niet langs elkander heen te praten, ons er bewust van blijven, dat de klaar1)lijkelijk door A. verdedigde opvatting inhoudt, dat „oud", ,ouder”, „oudst”, ,zeer oud" en "te oud" te zamen de primaire beteekenis van het woord vormen. Want dat men als een van de afgeleide beteekenissen „oud” enz. aanvaarden kan, geef ik, al zou ook uit een vorige beschouwing ${ }^{6}$ ) anders kunnen blijken, gaarne toe, voorloopig echter onder handhaving van de opvatting, dat men tot die afgeleide beteekenis even goed kan komen, wanneer men, zooals ik in mijn hierboven aangeduid opstel veronderstellenderwijze deed, van een primaire beteekenis ,magisch-gevaarlijk" uitgaat ${ }^{\tau}$ ). Wij behoeven ons dus voor het oogenblik slechts af te vragen, op grond waarvan A. in dit gedeelte van zijn betoog ,oud" enz. de primaire beteekenis van kabayan acht. En dan vinden wij als eenige antwoord, dat A. op deze, scherper gestelde vraag geeft: dat deze grondbeteekenis blijkt uit de correspondentie van kabayan tweemaal met het wṛddba en eenmaal met het jyeștha van de çloka's van het Sanskṛt Wirāțaparwan ${ }^{8}$ ), waarvan de door hem geciteerde passages van het OudJavaansche Wirățaparwa de weergave vormen. $\mathrm{Nu}$ lijkt het mij echter zeer twijfelachtig, of dit als een steekhoudend argument beschouwd kan ivorden. Dat toch elk spoor van stelselmatige bestudeering van de constructies en de eigenaardigheden der eigen taa! in de oudere Javaansche litteratuur ontbreekt, voor zoover thans nagegaan kan worden, en dat daartegenover regelmatig etymologische 
verklaringen voorkomen, die even zoovele getuigenissen zijn van de ongeschooldheid der exegeten, dat zijn twee feiten, die ons beletten in de weergaven van Sanskrt woorden door Oud-Javaansche auteurs - en ditzelfde geldt, zelfs wellicht in nog sterkere mate, voor de latere Balische verklaringen van Oud-Javaansche woorden - iets meer te zien dan practische verklaringen, waaraan alle wetenschappelijkheid vreemd is. Dat men dus wṛddha en jyeștha herhaaldelijk met kabayan verklaard vindt, bewijst op zijn hoogst, dat omstreeks 1000 A.D. de begripsinhouden van Oud-Javaansch kabayan en van Sanskṛt wrịddha en jyeștha elkander ongeveer en voor een deel gedekt hebben, doch wettigt nog volstrekt niet de conclusie, dat kabayan bij uitstek of naar zijn eersten zin toen „oud" beteekend heeft.

Wij hebben zoo even verondersteld, dat op de door A. geciteerde plaatsen kabayan de beteekenis van "oud" toegekend zou mogen worden. Intusschen zou ik voor een dier plaatsen die veronderstelling toch niet kunnen handhaven en voor een andere slechts als een mogelijkheid naast een andere mogelijkheid. Om met de laatstbedoelde plaats te beginnen: tegenover A.'s opvatting kan gesteld worden, dat het kabayan van Wir. 61,3 minstens even goed uit bhaya verklaard kan worden. Arjuna zegt er van Yudhișthira: Ana sira kaka ning ulun kabayan prasiddha katwang ing ulun ${ }^{9}$ ), hetgeen door A. als volgt vertaald wordt: „Ich habe einen älteren Bruder, den ältesten (von uns Brüdern), der berühmt ist ${ }^{10}$ ) und von mir verehrt wird". A. ziet zich hier gedwongen kabayan met een superlativus te vertalen, omdat een comparativus na kaka, dat zelf reeds ,oudere broeder" beteekent, volstrekt overbodig zou zijn, terwijl de vertalingen ,oud” en ,zeer oud” in strijd zouden komen met de voorstelling van het Mahābhārata, dat Yudhișțhira in dit gedeelte van het verhaal schildert als een man in de kracht van zijn leven. die straks nog zeer actief zal deelnemen aan den grooten achttiendaagschen strijd; dat de vertaling ,te oud” hier klaarblijkelijk allen zin zou missen, spreekt voorts vanzelf. Behoudens voor Wir. 39, 18, waar intusschen een overtreffende trap volstrekt niet onontbeerlijk is en waar A. trouwens zelf nog een andere vertaling aan de hand loet, gebruikt A. echter op geen der door hem aangevoerde bewijsplaatsen een superlativus ter vertaling van kabayan, zoodat wij het gebruik er van op deze plaats voorloopig gerust nog mogen beschouwen als te weinig gefundeerd. Het bhrātur.... jyeșțhasya van den correspondeerenden Sanskṛt tekst (Wir., IV, 1407), waarnaar A. verwijst, kan even goed op kaka betrekking hebben als op kaka en 
kabayan te zamen, en het is derhalve een open vraag, althans voor deze plaats, of wij inderdaad wel mogen spreken van een ,d $\mathrm{urch}$ die Sanskritvorlage bezeugte (spatiëering van mij, B.) Bedeutung von kabayan"10a).

Ten slotte zouden wij, wanneer wij eens aan de door A. verdedigde afleiding van kabayan wilden vasthouden, op deze plaats - en wel met het oog op de woorden katwang ing ulun, die op kabayan volgen - toch ook heel goed de verderop in zijn artikel door :A. zelf gegeven vertalingen ,weise”, ,erfahren”, „kundig”, ,klug”, ,hervorragend”, kunnen gebruiken, aangezien men ook in het bezit van deze eigenschappen een verklaring zou kunnen zien van de vereering, die Arjuna voor Yudhișthira aan den dag legt (,Ik heb een ouderen broeder, die wijs [resp. voortreffelijk] is en die (daarom dan ook) door mij met ontzag behandeld wordt"). Maar wanneer men eenmaal zoo ver is, wat voor bezwaar kan er dan nog tegen zijn, dat wij tot diezelfde verklaring komen via kabhayan, „magisch-krachtig",' daar immers het bezit van magische kracht dat van wijsheid (resp. voortreffelijkheid) met zich medebrengt? Ook de vertaling ,,eerbiedwaardig”, die nog dichter bij ,magisch-gevaarlijk” staat, zou hier goeden zin geven. In het kader van dezen gedachtengang zou men katwang ing ulun zelfs als een regelrechte verklaring van kabhayan kunnen beschouwen, zooals er in de OudJavaansche parwa's zoovele verklaringen voorkomen van woorden, die de auteur bij zijn publiek niet voldoende bekend veronderstelt.

De andere der beide hierboven bedoelde plaatsen, waar, naar mijn begrip van den tekst, de vertaling ,oud” niet in alle opzichten bevredigend is en vermoedelijk niet gehandhaafd zal kunnen worden, is Wirāțaparwa 94, 11. Daar motiveert koning Wirāța zijn besluit om van de heerschappij afstand te doen o.a. met de volgende woorden: tělas kabayan alawas ratu ngaran ing ulun, tělas jīrṇa warĕg ing wibhoga. A. vertaalt deze woorden aldus: „Ich bin schon zu alt und bin schon lange König, bin gebrechlich und satt der Genüsse”. Het zijn hier vooral eigenaardigheden van den context, die, naar het mij voorkomt, door A. niet zijn opgemerkt of althans bij A.'s vertaling niet voldoende tot haar recht komen, welke ons doen omzien naar een andere mogelijkheid van vertaling.

In de eerste piaats valt er op te merken, dat het aan het Sanskrt ontleende woord jīnna naast de beteekenis ,gebrekkig”, die het in laatstgenoemde taal reeds heeft, in het Oud-Javaansch die van „,verheugd”, ,zich verheugen”, ,genieten”, en, te oordeelen naar D1. 90 . 
añjīrṇani, „verzadigen”, ook die van „verzadigd” kan hebben ${ }^{\mathbf{1 1}}$ ). Deze beteekenissen nu zijn hier zeer zeker niet zonder meer te verwerpen, want in de eerste plaats ligt het begrip ,genieten" in het Javaansch zeer dicht bij het begrip „regeeren”, zooals o.a. blijkt uit de bekende Oud-Javaansche uitdrukking amukti wibhawa, ,de macht genieten” = ,regeeren”, later met behoud van de beteekenis veelal verkort tot amukti of mukti, en in de tweede plaats wordt jïrṇa hier onmiddellijk gevolgd door het woord warĕg (,,verzadigd”, hier : van genietingen), dat, zoo het al niet met jirna zelf synoniem mocht zijn, toch in elk geval gelijk te stellen zou zijn aan tělas jīrṇa, ,tot het einde toe genoten hebben" = ,verzadigd zijn (van iets)”. Deze opmerking over jïrna wordt hier gemaakt, omdat, indien het in het onderhavige geval inderdaad gelijk ware te stellen aan ,gebrekkig”, het gebruik van het woord uiteraard A.'s opvatting, dat kabayan met ,oud" te vertalen is, min of meer zou steunen. Thans zien wij echter, dat jïnna voor twee verklaringen vatbaar is, en dat er derhalve voor de verklaring van kabayan veel minder bewijskracht aan toegekend mag worden dan het geval zou zijn, indien A.'s vertaling juist en de eenig mogelijke ware.

Een tweede opmerking bij A.'s weergave is, dat hij, naar het mij voorkomt, over het hoofd gezien heeft, dat tĕlas, al moge het oorspronkelijk ook vrijwel dezelfde beteekenis gehad hebben als uwus - zooals thans in het Maleisch tĕlah en sudah vrijwel synoniem zijn -, en al mogen sommige afleidingen van tĕlas ook als gelijkwaardig aan de correspondeerende afleidingen van uwus te beschouwen zijn, toch zelf in het Oud-Javaansch, dat wij hier voor ons hebben, niet meer als aequivalent van uwus te beschouwen is. Uitgaande van de gemeenschappelijke grondbeteekenis van ,tot zijn eindpunt gekomen”, ,geheel voltooid”, ,,geheel geschied” enz., heeft uwus zich ontwikkeld in de richting van een tijdsaanduider, doch tĕlas in de richting van een graadaanduider, en voor zoover ik kan nagaan, komt eer uwus als graadaanduider dan tĕlas als tijdsaanduider voor ${ }^{12}$ ). Wanneer tĕlas voor een adjectief komt te staan, duidt het dus aan, dat aan een subject de eigenschap, die door het adjectief wordt uitgedrukt, in den hoogsten graad wordt toegeschreven; tĕlas jīnna - om een voorbeeld van dichtbij te nemen - beteekent, al naar de beteekenis, die men aan jïrna toekent, hetzij zoo gebrekkig zijn, hetzij zooveel genoten hebben of zoozeer verzadigd zijn, dat men zich geen hoogeren graad van gebrekkigheid, resp. van genot of van de bevrediging daarvan, kan voorstellen. Omdat nu tĕlas 
kabayan, gegeven het zinsverband, onmogelijk kan beteekenen „,den hoogsten graad van ouderdom bereikt hebben" = „niet ouder kunnen worden", en ,gereed gekomen met oud te worden" - als ware „oud worden" een werk, dat men op een bepaald punt zou kunnen afsluiten - al even onwaarschijnlijk is als ,in ieder opzicht een oud man" - welke laatste vertaling bovendien niet zou passen bij iemand als koning Wirāta, van wien men op grond van den samenhang der Mahābhārata-verhalen mag vermoeden, dat hij op het tijdstip, waarvan in onze passage van het Wirătaparwa sprake is, nog een heel levensstadium voor zich heeft, en die trouwens later nog actief aan den grooten strijd zal deelnemen -, daarom zien wij ons voor de noodzaak gesteld om aan te nemen, dat òf kabayan hier een anderen zin heeft dan A. veronderstelt, òf dat tĕlas hier een ongebruikelijke beteekenis heeft. En aangezien het voor de hand ligt, dat het best bekende woord in zijn bekende beteekenis gehandhaafd moet worden, ligt ook de conclusie voor de hand, dat wij ook in dit geval ons niet blind moeten staren op het wriddha van den correspondeerenden Sanskṛt tekst (p. 94, regel 9) ${ }^{\mathbf{1 2 a}}$ ), maar onafhankelijk daarvan kabayan zullen moeten trachten te verklaren. Mij dunkt, dat wij ook hier met de beteekenis ,eerbiedwaardig”, ,,in aanzien staan” — waartoe wij, zooals wij reeds zagen, zoowel van een kabayan $=$,oud” als van een kabhayan $=$,magisch-gevaarlijk" kunnen komen - tot een veel meer aannemelijke opvatting van de passage in kwestie kunnen komen. Tělas kab(h)ayan toch zou dan beteekenen: ,ik heb den hoogsten graad van aanzien bereikt", en zou in dezen zin uitstekend passen bij tĕlas jīrṇa warĕg ing wibhoga, dat, althans wanneer wij jïrṇa in de bijzondere Oud-Javaansche beteekenis en niet naar den Sanskṛt zin opvatten, in andere woorden hetzelfde te kennen geeft.

De derde opmerking ten slotte bij A.'s verklaring van Wir. 94, 11 is, dat ,(ich) bin schon lange König” in het Javaansch, of het nu Oud- of Nieuw-Javaansch is, op zich reeds moeilijk uitgedrukt kan worden door alawas $\operatorname{ratu}^{13}$ ); des te minder hier, waar met het oog op ngaran ing ulun, dat slechts een bij het zinsverband passende variant van het explicatieve ngarannya is, tĕlas kabayan alawas ratu op te vatten is als twee termen, waarvan de eene, alawas ratu n.l., den anderen nader bepaalt, of liever: nadrukkelijker en effectiever den begripsinhoud van den anderen term naar voren brengt en den lezer of hoorder inprent, doordat hij een technische term of een standaarduitdrukking of in elk geval een om een of andere reden bijzonder opvallende zegswijze is, waarvan waarde en 
beteekenis zonder meer duidelijk zijn. De $\bar{\top}^{\top}$ wijze, waarop alawas en ratu hier in nauw verband zijn samengebracht, gepaard met het gebruik van ngaran ing ulun, moet, bij ontstentenis van andere mogelijkheden van vertaling, leiden tot de opvatting, dat alawas-ratu - dan aldus te lezen, met een verbindingsstreepje tusschen de woorden te verstaan is als een javaniseering van het Sanskṛt wṛddharāja, waarvan de deelen door Javaansche synoniemen vervangen zijn, doch met behoud van de volgorde der bestanddeelen van het Sanskrt origineel ${ }^{14}$ ). De bedoeling van tělas kabayan alawas-ratu ngaran ing ulun is dus, dunkt mij : ,ik heb op het toppunt van macht gestaan [of: ,ik heb de grootste maat van vereering genoten, die denkbaar is”, ,ik heb den hoogsten graad van aanzien bereikt”], doordat ik (geweest) ben wat men noemt wṛddharāja [d.w.z. meer dan yuwarāja, die immers wel koning is, doch wiens macht nog beperkt is, doordat hij onder de contrôle van zijn vader, den wrddharāja, staat]". Deze vertaling geeft niet alleen een bevredigende verklaring voor alle moeilijkheden, die in deze bladzijden opgeworpen zijn, maar laat ook ruimte voor de opvatting, dat de Javaansche tekst wil zijn een weergave van het wṛddhaç ciram rājan van de voorafgaande Sanskṛt çloka; dit zal dan echter op te vatten zijn als een metri causa gekozen variant van ciram wṛddharājan, „reeds lang opperkoning" 14").

Slechts schijnbaar sterker staat A. bij zijn verklaring van het kabayan van Wir. 83, 4. Immers, wel vallen hier ongetwijfeld ,oud” en „kabayan” samen, doch de plaats levert geen enkel bewijs er voor op, dat „oud” ook de primaire beteekenis van het woord in kwestie is. Omdat men bij het bestudeeren van deze passage, waarin men een aantal vreemde woorden achtereenvolgens in het Oud-Javaansch verklaard vindt, wellicht meer dan anders geneigd zou zijn belang te hechten aan de parallellie tusschen de Sanskrt woorden en de Oud-Javaansche weergaven, zij er nog uitdrukkelijk op gewezen, dat in dezelfde passage duhkhita (Wir. 83, 1) slechts zeer gebrekkig vertaald wordt met ,,aanduiding van iemand, die pijn heeft, gewond (als hij is) in den strijd", en dat nirāça (Wir. 83, 6; met een korte slot-a te lezen!), „wanhopig”, wel practisch vrij aardig overeenkomt met ngaran ing tan anênambunya masiha, ,iemand, die in de verste verte geen sympathie heeft te verwachten" ${ }^{15}$ ), maar dat niettemin de Oud-Javaansche tekst toch niet bepaald als een definitie van het begrip nirāça is te beschouwen, daar hij nog van verschillende andere begrippen de omschrijving zou kunnen zijn. Als meer dan een onge- 
veer juiste weergave van wṛddha behoeven wij dus ook kabayan wel niet op te vatten.

Over het kabayan van Wir. 39, 18 kunnen wij kort zijn, daar A. zelf in het midden wil laten, of het hier met ,die Aeltesten" dan wel met ,die Vornehmsten” te vertalen is ${ }^{16}$ ). $\mathrm{Er}$ is voor de laatste dezer beide vertalingen, dunkt mij, zelfs wel iets meer te zeggen dan voor ,die Aeltesten”, aangezien wel uit den context blijkt, dat degenen, die hier aan het woord zijn, personen van aanzien en gezag zijn, maar geenszins, dat zij dit aanzien en gezag bepaaldelijk te danken hebben aan hun leeftijd. Waaraan de kabayan het op deze plaats dan echter wel te danken hebben, dat zij voorname personen zijn, blijkt uit den tekst evenmin als de aard en de graad van hun voornaamheid, zoodat wij Wir. 39, 18 als veel te vaag om er argumenten voor eenige opvatting omtrent de etymologie van het woord kabayan aan te ontleenen gerust buiten beschouwing kunnen laten.

Met betrekking tot het kabayan van Wir. 39, 35, dat toch wel op dezelfde personen slaat als dat van 39,18 , merkt A. ${ }^{17}$ ) op, dat het „wohl = javan. wong tuwå „Eltern, Vater oder Mutter” aufzufassen ist", en daar hij in noot 1 op p. $232-233$ tot de opvatting gekomen is, dat atandabalun een euphemistische uitdrukking is voor „,doode”, „overledene”, ,lijk”, vertaalt hij Iniring ta ya de ning atandabalun wwang kabayan met ,Sie wurden begleitet von der Mutter des Toten(?)"; in dezelfde noot zegt hij n.l. nog, dat ,,atanda balun wrong kabayan, ebenso wie in der vorigen Stelle kulawandhawa watěk kabayan, ein Tatpuruṣa-Kompositum (wäre), wie es im Anschluss an das Sanskrit hin und wieder im Kawi auftritt". Ik kan hierop niet anders zeggen dan dat ik A. op dezen weg van gewaagde gissingen niet volgen kan. Dat er in het Oud-Javaansch z.g. tatpuruṣa-samenstellingen kunnen voorkomen, die dan, gezien de regels van de woordverbinding in het Javaansch, in deze taal een hybridisch karakter dragen, hebben wij zoo even kunnen zien bij de bespreking van alawasratu, een voorbeeld, waarnaar A. met veel meer recht had kunnen verwijzen ${ }^{18}$ ) dan naar kulawandhawa watĕk kabayan, dat zich immers veel eenvoudiger als ,verwanten en kabayan's” of als hoofdwoord plus appositie - of desnoods als explicatieve samenstelling, ,,kabayanverwanten" = ,verwanten, die de positie van kabayan bekleedden" laat verklaren dan als „die Aeltesten (oder Vornehmsten) der Verwandten”, een vertaling, waartegen bovendien nog onoverkomelijke bezwaren van grammaticalen en syntactischen aard ingebracht kunnen worden. Maar om de in het Oud-Javaansch toch altijd nog vrij on- 
gewone tatpurușa te veronderstellen in een geval als dit hier, waarin wij toch eigenlijk maar raden moeten naar de beteekenis der componenten ${ }^{19}$ ), componenten, die op hun beurt bovendien nog samengesteld zouden zijn naar Javaanschen trant, dát lijkt mij, in gemoede, toch wel wat te ver te gaan!

Van het bespreken der andere voorbeelden, waarin kabayan volgens $\mathrm{A}$. zelf niet meer de oorspronkelijke beteekenis heeft, doch den afgeleiden zin van ,,chef” of ,,autoriteit”, kunnen wij gevoegelijk afzien. Het voorgaande recapituleerend stellen wij dus, dat A.'s opvatting, volgens welke uit de door hem geciteerde tekstplaatsen de primaire beteekenis ,oud” voor kabayan is vast te stellen, onhoudbaar is, waarmee echter nog niet gezegd wil zijn, dat kabayan niet in secundairen zin ,oud" kan beteekenen, en evenmin, dat het bewijs voor A.'s stelling niet wellicht te leveren zou zijn op grond van andere teksten en bewijsplaatsen ${ }^{20}$ ); een thesis van een zuiver negatief karakter dus, die niet praejudiceert op de waarde van resultaten, waartoe wellicht anderen zullen komen. $\mathrm{Nu}$ zal nader moeten blijken, of wellicht uit anderen hoofde aan kabayan de beteekenissen toegekend kunnen worden, die A. er aan gehecht wil zien.

In dit tweede gedeelte van ons betoog dient A.'s opvatting omtrent de vorming van het woord kabayan nader bekeken te worden. A. neemt, zooals reeds in de inleiding opgemerkt werd, aan, dat men kabayan heeft te beschouwen als een ka--ěn-vorm met de kracht van een excessivus, en uitdrukkelijk zegt hij nog eens, dat kabayan derhalve te vergelijken is met het Nieuw-Javaansche kĕtuwan. $\mathrm{Nu}$ durf ik zonder hieromtrent een nauwkeurig onderzoek ingesteld te hebben - voor zoover ik weet, heeft tot dusverre ook niemand anders voor het Oud-Javaansch een opzettelijk onderzoek aan deze vormen gewijd ${ }^{21}$ ) - geen definitief oordeel uit te spreken, doch mijn voorloopige indruk is, dat de ka--ěn-vorm als excessivus in het Oud-Javaansch überhaupt niet voorkomt. Het Kawi-BalineeschNederlandsch Woordenboek van van der Tuuk vermeldt s.v. -ěn het gebruik van dit suffix voor den excessivus niet, en een vluchtig onderzoek aan de hand van bekende nieuwere Javaansche excessiefvormen had een negatief resultaat ${ }^{22}$ ). Hoe dit echter ook zij, wanneer het Oud-Javaansch een excessivus, die met behulp van de affixen ka- en -ĕn gevormd is, mocht bezitten, dan mag men de eigen beteekenis daarvan toch maar niet zonder meer over boord zetten en den vorm in een andere beteekenis gaan gebruiken, zoodra de con- 
text met het gebruik van een excessivus niet in overeenstemming is te brengen! A. echter heeft, behalve in het voorbeeld Wir. 94, 11 - tegen welks interpretatie echter, zooals wij reeds zagen, ernstige bezwaren zijn in te brengen - , nergens de beteekenis ,te oud" te pas gebracht, die het huidige kĕtuwan heeft.

Zooals terloops reeds even is opgemerkt, komen er wel in het OudJavaansch ka--ĕn-vormen voor, doch zij hebben, naar het schijnt, niet de beteekenis van een excessivus ${ }^{23}$ ), en het veronderstelde grondwoord lijkt niet tot die woorden voor gemoedsaandoeningen en psychische gesteldheden te behooren, waarmede het suffix -ěn en meestal een der praefixen kapa-, kapi-, kama- en kami-, maar een enkelen keer ook ka-, wel verbonden worden ter vorming van adjectivische afleidingen, die aan een subject toeschrijven het ondervinden van die gemoedsaandoening of het gekenmerkt zijn door die psychische gesteldheid $\left.{ }^{24}\right)$. En aan den anderen kant schijnt kabayan in de beteekenis van ,oud” toch ook niet ondergebracht te kunnen worden bij die woorden, waarin het suffix -ĕn - gesteld al, dat het in dat geval met het praefix ka- vereenigbaar zou zijn - het behept zijn met een of andere onaangename eigenschap, het lijden aan een of andere kwaal te kennen geeft; althans is - en m.i. wel te recht - de beteekenis „last hebben van ouderdomsverschijnselen” voor kabayan nergens verdedigd geworden. Het komt mij derhalve voor, dat wij hebben af te wachten, welk adstructiemateriaal nog aangevoerd zal worden, om dan op grond daarvan eventueel een meer definitieve uitspraak te doen omtrent de houdbaarheid van dit gedeelte van A.'s opvatting ${ }^{25}$ ).

De heer de Wilde heeft in plaats van aan ka- plus -ĕn gedacht aan een afleiding met behulp van ka- en -an. Van wayah's nevenvorm bayah, zegt hij, kan een afleiding kabayahan gevormd worden, waaruit door samentrekking ${ }^{26}$ ) kabayan ontstaat; dit kabayan zou dan beteekenen ,de getroffene door een (bepaalden) leeftijd" en dit zou leiden zoowel tot ,op leeftijd zijn” als tot ,volwassen zijn”, waardoor dan tevens verklaard zou zijn, dat de kĕbayan nu eens als een oude en dan weer als een jonge man wordt voorgesteld. Ook tegen deze opvatting zijn er verscheidene bezwaren in te brengen. In de meeste gevallen is een adjectief, dat met ka- en -an gevormd is, passief en te stellen naast een actieven vorm met het achtervoegsel -i. $\mathrm{Nu}$ kan men inderdaad pogen de beteekenis van de passieve afleiding te achterhalen door te zien, waar men te land komt door over het ezelsbruggetje te gaan van, getroffen worden door (hetgeen het grondwoord aanduidt)", maar op vasten bodem komt 
men uiteraard toch slechts te staan, wanneer er een actieve vorm met -i in de beteekenis van ,iemand treffen met”, ,iemand voorzien van”, ,iemand toevoegen”, ,iemand aandoen” (datgene, dat door het grondwoord aangeduid wordt) bestaat of althans bestaan heeft. tot welken zich de passieve vorm met ka- en -an herleiden laat; in andere gevallen zal men doorgaans belanden in het rijk der wankele hypothesen. In ons geval echter is er van een actieven vorm amayahi (van wayah) of ambayani (van baya $=$ wayah) in de beteekenis van „leeftijd toevoegen aan”, ,iemand leeftijd bezorgen”, ,,iemands leeftijd verhoogen”, ,,iemand ouder maken”, voor zoover ik weet, nog nooit iets gebleken. En al behoeven wij nu niet altijd angstvallig vast te houden aan den eisch, dat er eerst een actieve vorm van correspondeerende beteekenis gevonden moet zijn, voordat wij aan het bestaan van een ka--an-vorm in de beteekenis van ,,voorzien zijn van" kunnen gelooven ${ }^{27}$ ), toch verhindert het ontbreken van elk spoor van amayahi of ambayani ons de oplossing van den heer de Wilde voetstoots te aanvaarden. Bijvoegelijke naamwoorden, die met ka- plus -an uit een grondwoord gevormd zijn en die onafhankelijk van een correspondeerenden actieven vorm met -i, dus zonder passief te zijn, de beteekenis hebben van ,getroffen door”, ,voorzien zijn van (hetgeen het grondwoord aanduidt)", kent het huidige Javaansch niet ${ }^{28}$ ); voor zoover ik weet, geldt hetzelfde voor het Oud-Javaansch, al moet ik dit laatste zeggen op grond van een persoonlijken indruk, bij ontstentenis alweer van een opzettelijk hierop gericht onderzoek ${ }^{29}$ ). Wij zonderen hier van onze beschouwingen uit die uit grondwoord plus ka- en -an gevormde adjectieven, die hetzij door praefigeering van een later weer weggevallen voorvoegsel a-, hetzij zonder vormverandering met zich mee te brengen ontstaan zijn uit een primair substantief, dat met ka- en -an gevormd is, en waaraan soms wèl de beteekenis ,,voorzien zijn van” kan toegekend worden ${ }^{30}$ ). Wij zonderen deze adjectieven hier uit, omdat er dan naast kabayan $=$,oud” een kabayan $=$,ouderdom” zou moeten bestaan of bestaan hebben; en al zou nu naast wayah een vorm kawayahan of desnoods kabayan in dezelfde beteekenis als het grondwoord heeft, ,leeftijd”, ,ouderdom” (in den zin van age), niet ondenkbaar zijn, elk spoor er van ontbreekt in elk geval, zoodat ook deze weg in het rijk der hypothesen blijkt uit te komen. Der langen Rede kurzer Sinn is, dat zoowel Aichele als de Wilde te ver gaan, wanneer zij meenen met kabayan, wat de wijze van vorming betreft. reeds in het reine gekomen te zijn; daarvoor stuiten hun oplossingen, 
zelfs al zouden de argumenten, die er tegen aangevoerd worden, niet als doorslaggevend beschouwd kunnen worden, op te groote bezwaren ${ }^{31}$ ).

Blijft ons nog over aan een onderzoek te onderwerpen A.'s opvatting, dat het grondwoord, waartoe kabayan te herleiden is, niet het gewone, uit Oud- en Nieuw-Javaansch bekende wayah is, doch een nevenvorm daarvan, baya. A. heeft ongetwijfeld gelijk, wanneer hij er op wijst, dat de w van het Sanskrtt in het Oud-Javaansch in een b kan overgaan en dat de slot-s van Sanskrrt s-stammen in het Oud-Javaansch kan verdwijnen ${ }^{32}$ ). Hier zouden wij intusschen te maken krijgen met een geval, dat èn wayah, de vorm, waarin, met de oorspronkelijke begin-w, de $-\mathrm{h}$ in plaats van de oorspronkelijke -s optreedt - een overgang, terloops gezegd, die uit het Sanskrrt en niet uit het Oud-Javaansch te verklaren is ${ }^{33}$ ) -, èn de vorm met verlies van de $\mathrm{s}$ en met overgang van de oorspronkelijke $w$ in een b, baya, in één taal zou optreden. En al is nu het optreden van doubletten op zichzelf alweer niet iets buitengewoons en behoeft de vorm baya dus nog niet gewantrouwd te worden alleen omdat er reeds een woord wayah bestaat, iets anders wordt het toch, wanneer wij in zake het optreden van doubletten in het Javaansch en met name ten aanzien van de oorzaak van het verschijnsel, dat soms de $-\mathrm{s}$ van Sanskrtt s-stammen in het Javaansch tot een $\mathrm{h}$ wordt, soms daarentegen verdwijnt, nog geheel in het duister tasten; wanneer er voorts geen andere gevallen aan te wijzen zijn van uit het Sanskrrt overgenomen woorden, die zoowel mèt als zonder $h$ in het Javaansch verschijnen; wanneer er in de derde plaats in het Javaansch zelf, waaruit het woord kabayan toch klaarblijkelijk stamt, van het veronderstelde grondwoord baya geen andere afleiaingen bekend zijn $\left.{ }^{34}\right)$, en wanneer er ten slotte ter verklaring van kabayan nog andere hypothesen bestaan, die tot dusverre niet op zakelijke gronden bestreden zijn geworden ${ }^{35}$ ) en die, naar het mij voorkomt, op veel minder bezwaren stuiten. In zoo'n geval toch is er, dunkt mij, alle aanleiding om met het in het geding brengen van het doublettenverschijnsel, waaraan een zekere zeldzaamheid toch in elk geval niet ontzegd kan worden, meer dan gewone voorzichtigheid te betrachten.

Van de parallellen, die A. in het Maleisch aanwijst, is ook niet alles einwandfrei te noemen. Hoewel ik niet met voldoende gezag hierover kan oordeelen, lijkt mij het baya van Pĕlayaran Abdullah, ed. Brons Middel, p. 67, dat A. citeert, toch te vreemd gebruikt te 
zijn om als ondubbelzinnig bewijsmateriaal dienst te kunnen doen. Het Maleische sabaya zal vermoedelijk wel met het Sanskrt wayas samenhangen, maar het is heel wel mogelijk, dat wij hier met een verhuizing van sawayas naar den Archipel te maken hebben, die niet in direct verband staat met de wijze, waarop wayas overgenomen is geworden, misschien doordat de twee woorden langs verschillende wegen en door verschillende dragers naar den Archipel zijn overgebracht; dit zou ons dan tevens ten minste eenige verklaring geven voor het anders - mij althans - onverklaarbare feit, dat het Javaansch den h-vorm wayah met niet in het Maleisch voorkomende beteekenissen heeft en het Maleisch den op een vocaal eindigenden vorm sabaya bezit, die aan het Javaansch vreemd is. Bovendien missen wij, hoezeer ook de waarschijnlijkheid voor samenhang tusschen het Maleische sabaya en het Sanskṛt sawayas pleit, de zekerheid, dat zulks inderdààd het geval is, daar er, volgens het Petersburger Woordenboek, in het Sanskṛt ook een woord wayā voorkomt, ,Zweig”, „Ast”, ,Geschlecht”, ,Sippe”, waarop, blijkens de beteekenisverschuiving, die het Javaansche en het Maleische bangsa tegenover het Sanskṛt wamça te zien geven (resp. ,soort”, ,slag”, en „Stamm”, „Geschlecht”), het Maleische sabaya (,,soortgenoot”) theoretisch eveneens terug te voeren is. Nog meer reserve past ten aanzien van het Maleische baya, waarvoor Klinkert ${ }^{36}$ ) ,slag, soort, in betrekk. tot den leeftijd" opgeeft, en vooral voor het Menangkabausche bayò, „ouderdom, leeftijd; hoog van leeftijd”, volgens van der Toorn ${ }^{37}$ ); het kàn geheel onafhankelijk van sawayas van het Sanskrtt wayas komen, doch de mogelijkheid dient in elk geval niet geheel uitgesloten te worden, dat het van wayā komt, en dat dus het Menangkabausch in bayò via ,leeftijdsklasse”, ,naar don lceftijd bepaald soort”, een beteekenisbeperking te zien geeft tegenover het Maleische baya, dat, wederom blijkens den overgang van het Sanskṛt wamça tot het Javaansche en het Maleische bangsa, niet zoo heel ver staat van de hierboven opgegeven beteekenis van wayā ${ }^{38}$ ); en nog meer kans is er, dat het door Rückbildung uit sabaya ontstaan is. - Waar het ten slotte op aankomt, is, dat er ook hier weer reden tot twijfel overblijft - ook al zou ik voor mij geenszins zoo ver willen gaan, dat ik ter verklaring van baya (bayò) en sabaya aan afleiding van Sanskṛt wayā de voorkeur zou willen geven! - en dat dus A.'s theorie met den gebrekkigen steun, dien het Maleische woord baya hem biedt, nog geenszins afdoende geholpen is.

Betreffen deze opmerkingen den vorm, waarin het Sanskṛt wayas in den Indischen Archipel optreedt, ook over de beteekenis van het 
woord is nog een opmerking te maken, al houdt deze niet zoozeer critiek op A.'s opvatting in. Het Petersburger Woordenboek geeft voor wayas op: „Kraft, körperliche und geistige, Gesundheit, Macht; Zeit der Kraft, jugendliches (spatiëering van mij, B.) Alter, Altersstufe überh., Lebensjahre". Gaan wij deze beteekenissen na, benevens de beteekenissen van de talrijke afleidingen van wayas, die het Petersburger Woordenboek opgeeft, dan zien wij, dat de beteekenis ,,jeugdige leeftijd”, ,,jeugdige kracht”, praevaleert, dat daarnaast het neutrale ,leeftijd" in vrij veel afleidingen optreedt, doch dat "hooge leeftijd" slechts als beteekenis van enkele afleidingen voorkomt, en dan meestal nog slechts, wanneer een met wayas samengesteld ander woord daartoe aanleiding geeft. In het Javaansch is de primaire beteekenis van wayah ,leeftijd”, in de neutrale beteekenis van het woord; dit geldt ook voor het Oud-Javaansch, blijkens cen plaats als A diparwa 109, 6-7, waar gesproken wordt van rare magawe doṣa ri pad-bĕlas tahun wayahnya, ,kinderen, die kwaad doen (zondigen) op den leeftijd van veertien jaar (en ouder)", en blijkens het nwam i wayah, ,,jeugd", dat van der Tuuk in het KBW., s.v. (1e), opgeeft en waar mwam het op zichzelf neutrale wayah, zooals men ziet, in één bepaalde richting differentiëert. Het Nieuw-Javaansche wayah in de beteekenis ,tijd van den dag” is wel als niet anders dan een variatie van het eerste wayah te beschouwen. Het Maleische sabaya gaat, gesteld dat het inderdaad van Sanskrt sawayas af te leiden is, al evenzeer op het neutrale „leeftijd” terug. Het NieuwJavaansche diwayah, waarmee de leeftijd van 16 tot 18 jaar wordt aangeduid, vormt geen uitzondering, althans wanneer wij mogen aannemen, dat het ontstaan is uit Sanskrt madhyawayas (,den leeftijd van het midden [n.1. tusschen jeugd en ouderdom] hebben of bereiken") via een *madewayah, waarvan de eerste lettergreep als een Javaansch praefix is aangevoeld en daarom verloren is gegaan mèt de verdwijning van het echte praefix ma-; mocht deze afleiding niet juist zijn, dan zouden we in diwayah, voorloopig in het midden latend, waar het woord dan wèl vandaan moet komen, een reminiscentie kunnen zien aan de beteekenis ,,jeugdige leeftijd”.

$\mathrm{Nu}$ moet men echter wayah natuurlijk praegnant gebruikt hebben, op dezelfde wijze als de Nederlandsche uitdrukking „op leeftijd zijn” (= „op hoogen leeftijd zijn”), om van het neutrale „leeftijd” van wayah tot het ,oud" van kabayan te kunnen komen. Dat zulks intusschen inderdaad wel het geval kan geweest zijn, had A. aannemelijk kunnen maken met een verwijzing naar het Menangka- 
bausch, waar, zooals wij reeds zagen, de neutrale beteekenis naast die van ,hooge leeftijd" voorkomt, en vooral ook naar het Balische wayah, waar de beteekenis "oud" en diverse schakeeringen daarvan (,,door en door rijp" van vruchten; ,zuur" van dranken; ,sterk” van thee; ,donker" van kleur; ,,vergevorderd" van zwangerschap; vgl. de beteekenissen van Javaansch tuwa) thans op den voorgrond staan en het neutrale ,leeftijd" meer op den achtergrond is gedrongen; verder ook met een verwijzing naar het Nieuw-Javaansche krama-inggil-woord wayah, „kleinzoon”, dat zijn beteekenis te danken kan hebben aan een vroeger wayah met de in onbruik geraakte beteekenis van ,grootvader" (vgl. Balisch wayah, ,grootvader”, ,grootmoeder”), naar analogie van andere, echt Javaansche woorden, waarmee zoowel de ascendent als de descendent in cen relatie wordt aangeduid, zooals buyut, „overgrootvader” en tevens ,achterkleinkind" ${ }^{39}$ ). Intusschen, hoezeer de waarschijnlijkheid er ook voor pleit, dat het Javaansch vroeger een praegnant gebruik van wayah in de beteekenis van ,hooge leeftijd" gekend moet hebben als uitgangspunt voor de ontwikkeling van een wayah of awayah in de beteekenis van ,hoogen leeftijd hebbend”, ,bejaard”, ,grootvader", toch laat zich, dunkt mij, ook de mogelijkheid althans wel verdedigen, dat wayah $=$,kleinzoon" zich langs een anderen weg dan via „hooge leeftijd” uit het neutrale „leeftijd” ontwikkeld heeft ${ }^{40}$ ). En het Menangkabausche bayò zoowel als het Balische wayah kunnen toch ook gereedelijk aanvaard worden als bewijzen, dat er plaatselijk in den Indischen Archipel in gebruik gekomen is een praegnante beteekenis van het doorgaans in meer algemeenen zin gebruikte woord; een ontwikkeling, die parallel zou loopen met die van de praegnante beteekenis van sommige Sanskṛt afleidingen van wayas, doch daarvan niet noodzakelijk afhankelijk behoeft te zijn, en die dus evenmin noodzakelijkerwijze plaats gevonden moet hebben overal, waar het woord wayah zich een plaatsje in den localen woordenschat verworven heeft.

Al zijn er dus ook aanknoopingspunten te vinden voor de door A. impliciet verdedigde stelling, dat wayah in het Javaansch de praegnante beteekenis van ,hooge leeftijd” gehad moet hebben, toch blijkt ook in dit onderdeel van A.'s bewijsvoering de onzekerheid grooter en het bewijsmateriaal gebrekkiger te zijn dan de positieve toon van zijn opstel zou doen verwachten.

Die positieve toon, die is het vooral - zoo zou mijn eindconclusie 
zijn -, waartegen men bij het zich vormen van een oordeel over A.'s bijdrage bezwaar voelt rijzen. Ik heb terloops reeds opgemerkt (p. 612), dat het niet de bedoeling van dit opstel is te beweren, dat A.'s opvatting op zichzelf onhoudbaar is. Wèl heb ik, naar ik hoop, aangetoond, dat vooralsnog het bewijs voor de juistheid der opvatting volstrekt niet is geleverd. $\mathrm{Er}$ is, ook naar mijn meening, ongetwijfeld iets voor de afleiding van kabayan van het Sanskṛt wayas te zeggen ${ }^{41}$ ), zoo goed als er bezwaren in te brengen zijn tegen de destijds door mij voorgestelde afleiding van bhaya. Zooals reeds is opgemerkt, kan ik toegeven, dat kabayan, wàt ook de oorsprong van dit woord zij, in het Oud-Javaansch onder meer ook „oud” kan hebben beteekend ${ }^{42}$ ). Maar zoolang de in het bovenstaande ontwikkelde bezwaren niet weerlegd zijn en geen solieder adstructiemateriaal ter verdediging van A.'s these te berde gebracht is, blijft het voor mij een open vraag, of er nu inderdaad wel meer voor wayas dan voor bhaya pleit; men kan van bhaya toch eveneens gemakkelijk tot een kabayan in de beteekenis van ,oud" komen, en de sprong van ,,magisch-gevaarlijk" naar aanduiding van personen of zaken, die thans niet meer als magisch-gevaarlijk beschouwd kunnen worden, is niet grooter dan de sprong van ,oud" naar aanduiding van jonge menschen, zooals de kěbayan van de Soendasche vertellingen en wellicht ook de jonge vrouw van de Sumatraansche adatrechttermen, waarop Mevr. Coster-Wijsman en Dr. van Hinloopen Labberton de aandacht vestigen ${ }^{43}$ ). Zoolang het echte, tegen alle critiek bestande bewijs niet is geleverd, stelle A.'s oplossing zich tevreden met een plaats onder de hypothesen, naast, niet boven de andere gissingen.

\author{
NOTEN BIJ : \\ NOG EEN PAAR OPMERKINGEN OVER HET WOORD \\ „KABAYAN”.
}

1) Het feit, dat van der Tuuk bijzonderheden over het woord kabayan geeft s.v. bhaya in zijn „Kawi-Balineesch-Nederlandsch Woordenboek” (IV, 1020 1021), dat hij een enkelen keer kabhayan spelt met bh, en dat hij ten slotte een kabayan-kabayan vertaa!t (p. 1021, regel 5) met ,zeer gevaarlijk v. e. ziekte”, geeft er natuurlijk wel eenige aanwijzing voor, in welke richting hij de verklaring zocht. Het is echter ook heel goed mogelijk, dat van der Tuuk bij het verzamelen van zịn gezevens kabayan slechts voorloopig onder bhaya heeft 
geplaatst, met de bedoeling om het een definitieve plaats te geven, wanneer hij daartoe voldoende gegevens zou hebben verzameld; van deze werkwijze treft men in het KBW. vele vocrbeelden aan. Men mag dus wel eenige, maar niet te veel waarde toekennen aan de plaats van vermelding van kabayan in het KBW.

2) Deel 88 van deze Bijdragen, p. 23-25.

3) Deel 90 van deze Bijdragen, p. 141 sqq.

4) Met toestemming van Dr. van Hinloopen Labberton citeer ik hieruit het volgende :

„Voor een „vrouwelijke” beteekenis van kěbajan zou ik U....nog willen wijzen op Adatrechtbundel XII, pag. 111, waar voor het Lampoengsch van Kroeï wordt vermeld kĕbajan, ,jong-gehuwde vrouw, die nog geene moeder is”, en ,kěbajan boenting", ,,een geschaakt meisje, dat in het huis der aanstaande schoonouders haar intrek heeft genomen".

Ten aanzien van de beteekenis heeft ook mij het „ratu angabhaya” wel voorgezweefd, maar ik heb ten slotte toch steeds gedacht aan eene door $U$ nog niet genoemde conjectutrr, waarhij ,kabajan” niets dan de objectieve en collectiveerende nevenvorm van ,ngahèhi” is, met den zin van ,staande over velen” of ook van ,,allen voorziende van” (zie v. d. Tuuk, deel II, pag. 362: mangabèhi = mangěmbuli, s.v. kahèh). Dit woord, [kabèh], in O. J. kabaih, is toch wel identiek met kwich (kwaih, kabaih), waaruit akèh (dialectisch okèh voor den metathesis-vorm a-wkèh). Semantisch zijn ,vele” en ,alle” ook dicht bijeen.

De zin van ngabèhi, .,staande over velen, of allen”, klopt voor „pangéran (nga)bèhi” bijv. zeer goed: de oudste zoon, desnoods van een bijvrouw en geen kroonprins, maar die dan toch over al de kinderen gezag heeft.

Kĕbajan als lid van het désa-bestuur, de uitvoerende arm van den loerah, gaande over ,alle” zaken en personen, maar ook de „uitdeeler” en brievenbesteller, en kěbajan als de jonge huisvrouw, die het huishouden regeert, niet meer een jong meisje in het ouderlijk huis is, kloppen zeer goed. Dat de $\mathrm{i}$-vorm in Midden- en Oost-Java met den an-vorm in het Westen correspondeert, is bekend genoeg.

Voor de grammatische vorming hebben we een analogon in den Balischen „klian”-titel, uit ka-lwih-an, kaloewihan, met nevenvorm „kliwon” (uit kliwwan, de voornaamste pasarweekdag zoowel als de titel). Van der Tuuk geeft als grondvorm van klian klih, ,volwassen, oud", tegenover kinderen etc., doch "lwih", „lěbih”, „verheven, meerdere”, is toch wel de wortel”.

Wat de schrijver onder ,objectieve en collectiveerende nevenvorm" precies verstaat, is mij niet geheel duidelijk; klaarblijkelijk wil hij kabayan ongeveer dezelfde beteekenis toekennen als ngabehi, maar waar dan het objectieve van kabayan in opgesloten ligt ? „Eer zou men mogen denken”, schreef ik o.a. dr. v. H. L. terug, ,aan het passief van ngabehi, dat dan echter kakabehan of eventueel kakabayan zou (1. had moeten) luiden. Indien kabayan uit kakabayan verkort ware, zou het kunnen beteekenen ,over wien velen (lees: allen) het bevel voeren” of „die vele (lees: alle) bevelen in ontvangst heeft te nemen”. Voor den dorpsbode en wellicht ook de kabayan van den Adatrechtbundel zou dit een passende benaming zijn, maar in de eerste plaats blijkt, voor zoover mij bekend is, nergens, dat kabayan uit kakabayan verkort is, en in de tweede plaats zou de figuur van nenek kabayan en van de Jav. Ken Bayan hiermee nog niet verklaard zijn". - Ook zou men moeilijk kunnen verdedigen, dat kabayan ontstaan is uit kabaihan, d.i. uit kabaih $=$ kabeh met het suffix - an ; in het tegenwoordige Javaansch althans vertoont de afleiding met -an, voor zoover ik weet (vgl. H. N. Kiliaan, ,Javaansche Spraakkunst”, p. 175-176), nooit wisseling van subject ten opzichte van het grondwoord, terwij1 men toch, wanneer men kabayan uit kabeh 
of kabaih zou willen afleiden, kabayan op een anderen persoon zou moeten laten slaan dan waarop kabeh betrekking zou kunnen hebben. Dr. v. H. L. is echter van de juistheid mịner opmerkingen niet overtuigd en schreef mij later, dat hij zijn meening in alle opzichten meende te moeten handhaven.

5) Een Nederlandsche vertaling van Aichele's artikel vindt men in Djåwå, deel 11 (1931), p. 147 sqq.

6) Zie Bijdragen, deel 85, p. 470 (beneden) naast p. 472 (boven), waar ik nog geneigd was de beteekenis ,oud" geheel te verwerpen en slechts de vereenigbaarheid van de begrippen "oud” en „kabayan” te accepteeren. Mevr. CosterWijsman gaat in haar "Wilespiegel-verhalen in Indonesië”, p. 22, niet verder dan de opmerking: ,.... Daar nu kebajan in het O. Jav. ook (cursiveering van mij, B.) de betekenis ,oud" heeft...." enz., en onthoudt zich van bespiegelingen omtrent de etymologie van het woord. Mijn vorige bijdrage behoeft dus te haren voordeele een correctie, die ik hier gaarne aanbreng; men schrappe op p. 470 den zin: „In de eerste alinea echter komen opmerkingen voor, die ik minder graag voor mijn rekening zou nemen." (regel $7-6$ v. o.), en de vraag in regel 5-4 v. o. vervange men door "Nu doet zich echter de vraag voor, of het woord kahayan ook primair de beteekenis "oud" heeft".

“) De overgang ligt in dat geval in de beteekenissen „ontzagwekkend”, ,eerbiedwaardig”, ,eerwaardig”.

8) Respectievelijk van de Sanskṛt çloka's, die men in het Oud-Javaansche Wirātaparwa vindt. Uir A.'s woordenkeus en uit het feit, dat hij alleen voor de passage Wir. 61, 3 naar een vers van den Voor-Indischen tekst verwijst (IV, 1407), kan men reeds opmaken, dat de herkomst van sommige çloka's twijfelachtig is. Wir. 83, 3-4, verklaart een wrddha, dat voorkomt in de çloka van (Oud-Javaansch) Wirāțaparwa 82, 35-36, die, volgens aanteekening van den uitgever, Dr. H. H. Juynboll, in noot 3 op p. 82 , niet in den Sanskṛt tekst voorkomt. Hetzelfde geldt, blijkens noot 2 op p. 94, van de Sanskṛt çloka in (Oud-Javaansch) Wirāțaparwa 94, 9-10, die men in 94, 11 sqq. uitgewerkt vindt.

9) Af en toe heb ik de spelling van de Oud-Javaansche teksten een weinig veranderd om haar in overeenstemming te brengen met het systeem, waaraan ik mij gewend heb.

$\left.{ }^{10}\right)^{\circ}$ Terloops zij opgemerkt, dat men prasiddha ook in eng verband met het volgende katwang zou kunnen vertalen (,voor wien ik werkelijk, inderdaad respect heb", „die er in geslaagd is mijn respect af te dwingen” $>$, voor wien ik een ingeworteld respect koester"); in dat geval zou het hier vrij dicht komen bij het gebruik van sida in het huidige Javaansch en van sida en prasida in het huidige Balineesch.

10a ) Nog meer gaat men twijfelen aan de mogelijkheid om volgens de hier door A. toegepaste methode van vergelijking tot betrouwbare resultaten te komen, wanneer men de door hem geciteerde passage met de geheele Sanskṛt çloka vergelijkt alsmede met het laatste deel van pag. 60 . In $60,37-38$ zegt Uttara tot Wrihannala: „Maar welk een tot volmaaktheid opgevoerde plichtsbetrachting (deugdzaamheid) heeft $U$ dan wel gedreven, dat gij eunuchendom hebt willen aanvaarden (het leven van een hermaphrodiet hebt willen leiden)?" Daarop zegt Wrihannala: „Zoo zoo, dus wenscht gij, UUttara, mijn geschiedenis (levensloop, levensomstandigheden) te leeren kennen?! Welnu, luister dan naar wat ik $\mathrm{U}$ thans zegsen ga:

Op bevel van mijn oudsten broer houd ik mij een jaar aan deze gelofte en beoefen ik de practijk van (uit religienze of ethische motieven vrijwillig aanvaarde) gehoorzaamheid. Naar waarheid zeg ik $U$ dat.

Ik heb een ouderen broeder, kabayan, voor wien ik een ingeworteld respect 
koester. Hij nu heeft mij bevel gegeven om, met den tijd van een jaar tot termijn, de gelofte van kuischheid in acht te nemen. Ik ben werkelijk waarheidsprekend tegenover U".

Reeds uit deze vertaling, die ik met opzet zoo dicht mogelijk bij den tekst heb laten aansluiten, blijkt, dat de Sanskṛt çloka (vertaling hiervan cursief) en de Oud-Javaansche paraphrase er van wel in het algemeen, maar geenszins in détails met elkaar overeenkomen. Vooral frappeert ons het feit, dat het kabrahmacaryan van 61,4 eigenlijk geen vertaling is van het bratacaryām van 61,2 , maar berust op een vergissing van den vertaler, welke voor een deel te verklaren is uit de overeenkomst in klank tusschen bratacaryā en brahmacarya en voor een ander deel haar oorsprong vindt in het kanapungsakan van 60,38; intusschen zijn kanapungsakan (,het geen man, [noch vrouw] zijn”, ,eunuchendom" of „hermaphroditisme”) en kabrahmacaryan („coelibaat”) twee geheel verschillende toestanden, al hebben zij beide onthouding van geslachtelijk verkeer tot effect! Voorts vinden wij de zinsnede ,voor wien ik een ingeworteld respect koester" in de çloka in het geheel niet terug. Wanneer wij nu in de Oud-Javaansche weergave van deze çloka twee belangrijke afwijkingen constateeren en nog verschillende andere, kleinere vrijheden, dan mogen wij toch niet verwachten juist bhrātur... jyeșthasya welbewust nauwkeurig vertaald te vinden? - Men vergelijke nog de opmerkingen op p. 610 en in noot $12^{\mathrm{a}}$ ).

11) Ik kan hier op de beteekenisontwikkeling van dit woord niet ingaan, doch hoop èr in ander verband op terug te komen.

12) Ik heb, voor zoover ik weet, nooit tĕlas in de beteekenis van wis of (u) wus ontmoet, maar natuurlijk kan ik mij vergissen of kan het wel in die beteekenis voorkomen in werken, die ik nog niet heb leeren kennen. Een uiteraard vluchtig - onderzoek in het KBW. leverde geen aanwijzingen tegen mijn meening op. Juynboll geeft in zijn Woordenlijst s. v. tělas de beteekenis „reeds” op voor één plaats, n.1. Nāg. 22, 2, c, doch wanneer men dien tekst naslaat, zal men opmerken, dat Juynboll's weergave niet gelukkig is en dat tělas apagěh er even goed kan beteekenen „,volkomen vaststaan”, „dat zóó gefundeerd was, dat er eigenlijk niets meer nader te bevestigen viel”, „dat reeds over alle waarborgen voor het behoud van zijn aloude rechtspositie beschikte, die het maar wenschen kon”, of wel „dat reeds een historische positie innam” > ,met welks rechten als met iets vanzelfsprekends rekening werd gehouden"; in het kader van de vertaling van Poerbatjaraka (Bijdragen, deel 80 , p. 225) zou men het kumnen opvatten als „een thans definitief geregelde rechtspositie krijgen"; in al deze vertalingen heeft tĕlas zijn gewone beteekenis.

${ }^{12 a}$ ) Het is waar, dat bij vergelijking van de çloka van $94,9-10$ met de paraphrase, die er op volgt, de verleiding om wṛddhaç met kabayan, ciram met alawas en rājan met ratu gelijk te stellen groot is, maar de vraag is toch, of wij er aan toe mogen geven, wanneer wij zien, dat ook hier overigens geen sprake kan zijn van parallellie tot in détails. De bedoeling van de çloka is mij echter niet geheel duidelijk, zoodat ik in dit geval mijn opvatting niet in bijzonderheden kan toelichten.

13) Lawas zou in het huidige Javaansch ò praedicaat moeten zijn bij een subject, dat ,het koning zijn”, ,het regeeren als koning”, zou moeten beteekenen, of deel van een praedicaat, welks andere stuk ,koning zijn” zou moeten beteekenen en waarin het woord voor ,koning" voorafgegaan zou moeten worden door een adjectief met de beteekenis van ,zijn”, ,worden”, ,optreden als”. Zonder de kwestie te kennen, waarom het hier gaat, schreef mij de heer Prijono te Leiden, dat de volgende Javaansche zinnen ons ,ik ben reeds lang koning" kunnen weergeven: 1o. Ingsun wus suwe jumĕnĕng nata (ratu) ana 
ing nĕgara.... [of in het krama: Kula sampun dangu juměněng (tegenover een gelijke of mindere) resp. dados (tegenover een meerdere of oudere) nata wontěn ing něgari...?, wanneer èn het koning zijn van den spreker, èn de lange duur van het koningschap als niet bekend verondersteld wordt; 20 . Ĕnggon-ingsun juměněng nata wus suwe, of Wus suwe ěnggon-ingsun jumıeněng nata, wanneer het koning zijn van den spreker bekend verondersteld wordt, en wanneer „,reeds lang” met nadruk gezegd wil worden; 3o. (Yen) ingsun wus suwe ěnggon-ingsun juměnĕng nata, wanneer de nadruk valt op het subject en het koning zijn van den spreker bekend wordt verondersteld; 4o. [Dadi sira iku saiki wus dadi patih:] yen ingsun wus suwe juměněng nata, wanneer de nadruk valt op het subject, doch het koning zijn van den spreker als niet bekend verondersteld wordt; 5o. Ingsun (met stemverheffing) wus suwe ěnggon-ingsun jumĕněng nata, als antwoord op de vraag Sapa kang wus suwe ěnggone jumĕnĕng nata?, of Ingsun (met stenverheffing) wus suwe juměnĕng nata, als antwoord op de vraag Sapa kang wus suwe jumĕnĕng nata? - Zooals men uit deze voorbeelden van den heer Prijono ziet, wordt in het huidige Javaansch nooit lawas onmiddellijk naast het woord voor „koning” geplaatst; voor het Oud-Javaansch zị verwezen naar de opmerkingen op p. 633 (onder de Addenda).

14) $\mathrm{Zie}$ de opmerkingen over tatpurusa-samenstellingen in het Javaansch op p. $611-612$ en in noot 17 (slot) en 18 .

$14^{a}$ ) In het gewone çloka-type is wṛddharājan metrisch niet bruikbaar, daar de zesde lettergreep er lang in moet zijn.

15) Ter verduidelijking van de constructie van ngaran ing tan anênambunya masiha voeren wij hier voor het gemak even twee personen in: $\mathrm{A}=$ de wanhopige en $\mathrm{B}=$ degene, die hem helpt en hem dus van zijn wanhoop bevrijdt. $B$ is het subject van ana, van inambu en van masiha; masiha beteekent „lief zullen hebben”, „een liefdedienst zullen bewijzen”, „barmhartigheid (vriendschap) zullen betoonen" enz.; inambu is het passief van angambu, ,ruiken”, dat met een persoon tot object - die dus het subject van den passieven vorm is - beteekent ,ten aanzien van iemand een vermoeden hebben”, ,ten aanzien van iemand de lucht (er van) krijgen, (dat hij dit of dat doen zal)"; ana inambu -..... masiha beteekent dus: „er is iemand, van wien.... verwacht, dat hij barmhartig (hulpvaardig) zal zijn,.... helpen (redden) zal". Het suffix van inambunya slaat op A. De heele zin tan anênambunya masiha, waarin B subject is, wordt nu gebruikt om A, die niet op andere wijze dan als suffix van inambunya uitgedrukt is, nader te bepalen, en is dus een soort van samengesteld adjectief (een zin-adjectief, een adjectivische zin), dat (die) toegevoegd wordt aan een verzivegen substantief, of, als men wil, een als substantief gebruikt samengesteld adjectief. Er staat dus letterlijk: „naam van een niet-iser-iemand-van-wien-hij-hulp-verwacht" $>$, ,naam van iemand, van wien men zeggen kan, dat er voor hem niemand bestaat, die hem, naar hij hoopt, vriendelijk gezind zal zijn". - - De constructie leek mij te merkwaardig om haar hier niet te signaleeren. Men vergelijke hiermee mijn opmerkingen over het tan ana waneh van Arjunawiwāha 10, 1, b in Bijjdragen, deel 90, p. 176, en over het samengestelde adjectief in Wiwoho-Gericke 7, 12, aldaar p. 235, noot 76.

16) Loco citato, p. 232: „Die an diesen Stellen durch die Sanskritvorlage bezeugte Bedeutung von kabayan findet sich noch zweimal im Wirățaparwa: Draupadi, die Gattin der fünf Pānḍawa, die unter dem Namen Sairindhri als Kammerzofe in König Wirāțas Schloss geweilt hatte, wird zum Leichenverbrennungsplatze geführt, um dem Minister Kicaka, der ihr nachgestellt hatte und deshalb von ihrem Gatten Bhima getötet worden war, in den Tod zu

D1. 90. 
folgen. Da kommt ihr Bhima in schreckhafter Verwandlung zu Hilfe. Entsetzt rufen die Verwandten Kicakas (Wir. p. 39):

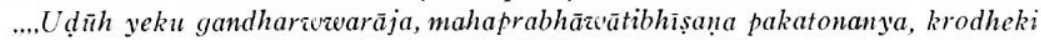
ta kabeh niyatanya. Toh ndak luputi tali ikeng Sairindhri, marapwan kita tan katěkan wiṣti mahābhaya!"

Ling ning kulawāndhawa watěk kabayan mangkana, lumuputi sang Sairindhrī. Malay'ū ta yomungsì nagara, z'urung gumaway $i$ kabhasmyan ikang Kìcaka.

„Weh, das ist der Gandharvenherrscher, übermächtig und schrecklich ist sein Anblick! Ohne Zweifel ist er ganz von Zorn erfüllt. Schnell, wir wollen die Sairindhrī losbinden, damit wir nicht in zu schreckliche Bedrängnis geraten!"

So sprachen die Aeltesten (oder: Vornehmsten) der Verwandten des Kicaka. Und sie banden die Sairindhri los. Dann liefen sie, um die Stadt zu erreichen".

Aber auf dem Wege werden sie von Bhīma hingemordet".

17) Loco citato, p. 232-233: „Die Fortsetzung der Erzählung enthält dann noch einmal das Wort kabayan, und zwar in der Zusammenstellung zereang kabayan, die wohl $=$ javan. wong tuwå „Eltern, Vater oder Mutter” aufzufassen ist:

Nihan strī nikang Kīcakawāndhaz'a kabeh, ya ta lumumpat mareng çmaçāna, milwānangaskāra çaze sang madihyang abhiprāyanya kabch. Iniring ta ya dening atandabalun ${ }^{1}$ ) wrwang kabayan.

„Nun machten sich die Frauen der Kïcakasippe eilends auf den Weg zur Leichenstätte in der Absicht, an der Totenfeier für den Hingeschiedenen teilzunehmen. Sie wurden begleitet von der Mutter des Toten(?)”".

Bij $\left.{ }^{1}\right)$ teekent Aichele aan: „Die in v. d. Tuuk's Kawi-Balineesch-Nederl. Woordenboek II 569, IV 980 offenbar vorausgesetzte Bedeutung von atanda balun = „mit Baumwoll-Flagge" befriedigt nicht. Ich vermute, dass der Ausdruck mit madures. atasmak balun „eine Baumwollbrille aufsetzen”, d. h. „,tot” synonym ist. Auf das Gesicht eines Toten wird nämlich balun (Baumwolle) gelegt. Vg1. Kiliaan, Madoereesch-Nederlandsch Woordenboek, 1904, I p. 331. Wörtlich würde der euphemistische Ausdruck atanda balun also bedeuten: „das Baumwoll-Zeichen tragen”. Danach wäre atanḍa balun arwang kabayan, ebenso wie in der vorigen Stelle kulaz'andhazua watĕk kabayan, ein Tatpurușa-Kompositum, wie es im Anschluss an das Sanskrit hin und wieder im Kawi auftritt". In het voorbijgaan merk ik op, dat blijkens een gewone Javaansche uitdrukking als cilik-mula, alit-mila, ,van kindsbeen af”, de beperking im Kawi zou kunnen vervallen.

18) Wij moeten hier bovendien niet over het hoofd zien, dat alawas-ratu de weergave van een technischen term is, die uiteraard zijn bijzonderen begripsinhoud gemakkelịk kan verliezen bij overbrenging in een taal van een geheel andere constructie. Vooral in zulke gevallen zal men geneigd zijn het taaleigen op te offeren aan de behoefte tot nauwe aansluiting aan het origineel. $\mathrm{Zie}$ ook mijn opmerking in Bịdragen, deel 90, p. 199, over de weergave van Sanskrt woorden in een Balische paraphrase van de Arjunawiwāha.

19) De opmerkingen, die A. in de hierboven (noot 17) afgedrukte aanteekening makt, zijn n.1., naar mijn meening, volstrekt niet overtuigend. Dat van der Tuuk de beteekenis „mit Baumwoll-Flagge” „offenbar vorausgesetzt” zou hebben, kan ik niet beamen: althans heb ik de overwegingen niet terug kunnen vinden, die A. tot deze meening geleid kunnen hebben. Van der Tuuk verwijst onder bālun naar taṇḍa en geeft daar „taṇ̣̣a bâlun wwang kabhajan, Wir. 28", zonder eenige opmerking. Meestal maakt van der Tuuk geen opmerkingen, wanneer hij in een tekst niets moeilijiks ziet of wanneer de tekst hem niet duidelijk is; ik geloof, dat hị zich in dit geval geen meening over atậ̣̣a balun 
gevormd heeft, of, zoo dit wel het geval mocht zijn, het raadzamer geacht heeft een nog niet gerijpt denkbeeld maar niet te publiceeren. Indien men A. in zijn meening ten aanzien van balun, waarvan ik bij gebrek aan gegevens de waarde voor het Javaansch niet behoorlijk weet te beoordeelen, maar die op het eerste gezicht niet verwerpelijk lijkt - daar in het tegenwoordige Javaansch walun voorkomt ter aanduiding van een soort doek en er in het Balisch, naar de opgave van van der Tuuk, van kapas abalun, ,één balun aan kapok", gesproken kan worden -, een eind weegs zou willen volgen, zou men, om de onmogelijke tatpuruṣa-constructie te vermijden, atanda-balun wellicht in plaats van op den dooden Kicaka kunnen laten slaan op degenen, die zich opmaken om het lijk te gaan verzorgen, en die dan wel de boomwol als teeken van den aard van hun uittocht zichtbaar met zich meegevoerd kunnen hebben. Met deze wijziging van de interpretatie van atanda-balun zou echter de passage voor $\mathrm{A}$. noch aan bewijskracht winnen, noch verliezen, aangezien wij er toch in geen geval voor de verklaring van kabayan iets uit kunnen leeren.

Er moge hier op nog eenige andere mogelijkheden ter verklaring van deze duistere uitdrukking gewezen worden. Met de onderhavige Wirātaparwa-passage vergelijke men het fragment Tjt. 36 sqq. in KBW., III, 119-120, waar verteld wordt, dat Çakuntalā's zoon Dewabāsu, die patih Cidrawa van koning Dursanta (= Dușyanta) heeft neergestoken, door 400 kariñu (III, 119b, regel 6 v. o.) achtervolgd wordt, die later (III, 120a, regel 11) wwang atanda genoemd worden. Zoowel de context als het Maleische mariñu (Portugeesch marinho; Klinkert: „Port. schout, inspecteur van politie”), waarop van der Tuuk s.v. kariñu zich beroept, wijst er op, dat wwang atanda hier ambtenaren zijn, die belast zijn met het handhaven van de veiligheid en de orde. Deze beteekenis zou ongetwijfeld op onze Wirāțaparwa-plaats uitstekend passen. Voor balun, dat dan als een apart woord beschouwd zou moeten worden, moge verwezen worden naar Juynboll's „Kawi-Balineesch-Nederlandsch Glossarium op het Oudjavaansche Râmáyạ̣a" ('s-Gravenhage 1902), s. v., waar men het abalun van Rām. 24, 252, c door den Balischen exegeet met manggawanin verklaard vindt; nggawanin nu is, volgens KBW., IV, 734b, s. v. gawa II, „(een menigte) aanvoeren”, „over (iemand) als hoofd gesteld zijn”, door van der Tuuk wel te recht in verband gebracht met punggawa. De beteekenis punggawa nu zou naast atanda $=$,politiebeambte(n)” en naast kabayan als naam van een of anderen magistraat natuurlijk heel goed passen, en omgekeerd vermindert de mogelijkheid, dat abalun - dat hier op onze Wirāțaparwa-plaats even goed gelezen kan worden (atanḍ̂balun) als balun (ataṇ̣a balun) - de naam van een overheidspersoon kan zijn, de kans, dat wwang kabayan ,ouders”, „vader” of „moeder” beteekent.

Opmerkenswaardig is, dat Juynboll in zijn „Oudjavaansch-Nederlandsche Woordenlijst" van 1923 voor het abalun van Rām. 24, 252, c de beteekenis „vaderloos" opgeeft, en dat nog wel zonder vraagteeken. Het is mij ook ten aanzien van deze vertaling van abalun niet mogen gelukken te weten te komen, waarop zij berust. Voor zoover ik zie, geeft de context - een beschrijving van de drukte onder de apen vóór het vertrek van den wonderwagen Puṣpaka; vgl. Yuddhakāṇda 122; Jacobi, Das Râmâyaṇa, p. 187 - geen aanwijzing in die richting, doch ik heb het onderzoek er van niet geheel kunnen voltooien; Gorresio's vertaling, die ik raadpleegde (deel 10, Parijs 1858, p. 247-248), bracht slechts aan het licht, dat de betrokken passage van het Sanskṛt Rāmāyaṇa heel anders loopt dan die van den Oud-Javaanschen tekst, en dat de namen van de apen, die de kakawin noemt, in het origineel op de correspondeerende plaatsen in het geheel niet voorkomen. Ik heb mij afgevraagd, of er samenhang zou kunnen bestaan tusschen Juynboll's vertaling ,vaderloos” en het feit, dat 
walu, Balisch balu, dat er in klank nogal op lijkt, de verwante beteekenis van „weduwnaar" en ,weduwe” heeft en het daarvan afgeleide kawalwan, kawalon, N.-Jav. kuwalon, ,stief-”, vooral „stiefkind”, een nog dichter bij „,vaderloos” komende beteekenis, maar een bevredigend antwoord heb ik op die vraag niet gevonden. Maar mòcht het zijn, dat abalun inderdaad „vaderloos” zou beteekenen, dan zou de overgang naar „ambtenaar”, ,'s vorsten dienaar”, niet zoo heel vreemd zijn, gezien het feit, dat het op Bali gewoonte geweest is, dat weesjongens zonder bloedverwanten door den vorst tot zich genomen en voor zijn dienst opgeleid werden (Djajaprana, ed. Volkslectuur, No. 335, p. 2); het lijkt niet uitgesloten, dat deze rechtsregel op Java vroeger eveneens gegolden heeft.

20) Zie hierover de opmerkingen op p. 619 en in noot 41.

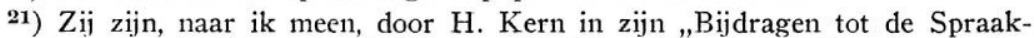
kunst van het Oudjavaansch” (,Verspreide Geschriften”, deel 8 en 9) niet behandeld.

22) Dit behoeft natuurlijk niet te verbazen, want onder de talen, die veel overeenkomst met het Javaansch vertoonen, zijn er maar enkele, die een excessivus bezitten. Het lijkt dus geenszins a priori uitgesloten, dat het huidige Javaansch, waaronder wij toch meestal het dialect van Midden-Java verstaan, een excessivus zou bezitten, en het Oud-Javaansch, dat een Oost-Javaansch dialect is, daarentegen niet.

23) Zoo geeft het KBW. s. v. wĕlas een vorm kaw(ě)lașĕn, die door de Balische commentatoren met mār gelijkgesteld wordt, doch waarvoor geen vindplaats wordt opgegeven. S. v. çarama geeft het KBW. een vorm kahangĕtĕn voor Hw. 32, 19 sq., blijkbaar in den zin van ,in vuur raken”, ,zich druk voor iets (gaan) maken", ,.verhit”, ,ingespannen bezig”, waarnaast Juynboll, Wrd1., een vorm kahangětan, ,verhit”, geeft voor Rām. 24, 103. Voor de wisseling van -ĕn en -an zie men ook de volgende noot. Vormen als kadadin en kaprabhun, waarvoor men later kadaden en kaprabhon zegt, zou men ook kunnen opvatten als ka--ěn-vormen, die de pěpět, conform den voor het Oud-Javaansch geldenden regel, verloren hebben onder invloed van de voorafgaande vocaal; in dat geval zouden er dus ook ka--ěn-substantieven in het Oud-Javaansch bestaan hebben, hetzij als prototypen, hetzij als nevenvormen van de ka--an-substantieven, die in de latere taal algemeen gebruikelijk zijn. Men kan echter ook aannemen, dat in het Oud-Javaansch de a en de $i$, resp. de a en de $u$, nog samengetrokken werden tot $i$ resp. $u$ in plaats van tot e resp. tot $o$, een mogelijkheid, waarvoor ook een vorm als pungkur, van een grondwoord ungkur met praefix pa-, pleit.

24) In plaats van het suffix -ĕn komt in zulke vormen echter ook wel -an voor, terwijl zelfs het suffix wel eens geheel ontbreekt. Zoo kent het OudJavaansch vormen als kamatěnggěngěn, kamitěnggĕngěn, kapiwělasan, kapitěnggěng, kamitěnggĕng, kapiwělas, kapihĕnĕng enz.

25) Gonda wil, naar hij mij mondeling mededeelde, het hier geformuleerde bezwaar tegen A.'s opvatting vermijden door wayah als ,jeugdige levenskracht" op te vatten, en kabayan dus als ,iemand, die een surplus heeft aan jeugdige levenskracht" $>$,iemand, die over meer çakti beschikt dan gewone menschen"; uit deze grondbeteekenis zouden zich de verschillende toepassingen, die het woord kabayan in den loop der jaren in de verschillende Indonesische talen gevonden heeft, vrij eenvoudig laten verklaren. Deze opvatting stuit op minder bezwaren dan die van A., doch accoord kan ik er toch nog niet mee gaan. Want in de eerste plaats is ook deze opvatting van de voorwaarde afhankelijk, dat het Oud-Javaansch inderdaad een excessivus moet bezitten, en in de tweede plaats gaat Gonda wellicht gemakkelijker van den excessivus naar den absoluten superlativus over dan mij zonder argumenten toelaatbaar 
lijkt. Immers, hoe moet men zich het te veel hebben aan jeugdige levenskracht voorstellen? Er bestaat daarvoor toch geen niet te overschrijden grens? Daarom maakt Gonda er ,buitengewoon veel” van, een ontwikkeling, die men op zichzelf wel aannemelijk maken kan, doch die voor het Javaansch ook feitelijk aangetoond zou moeten worden, wilde zij zonder meer acceptabel zijn.

26) Er zij echter de aandacht op gevestigd, dat de slot-h van Javaansche woorden nict wegvalt bij aanhechting van met een vocaal beginnende suffixen, en dat er dus ook geen contractie plaats vindt van die vocaal met den klinker, die in het grondwoord aan de slot-h voorafgaat; wel geschiedt dit af en toe in poëtische vormen, doch dan zondigt men daarin klaarblijkelijk tegen het natuurlijke klankeigen om te kunnen voldoen aan de eischen van de metriek of aan zijn zucht tot ongewoon-doenerij. De voorbeelden, die de heer de Wilde geeft, zijn dan ook niet aan het Javaansch ontleend. En het is vermoedelijk ook wel om deze moeilijkheid te ontloopen geweest, dat A. de verklaring gezocht heeft bij baya als nevenvorm van wayah.

27) De mogelijkheid bestaat n.l. theoretisch steeds, dat er in gevallen, waarin een actieve i-afleiding van het grondwoord ontbreekt, door analogiewerking een semasiologische verhouding tusschen het grondwoord en zijn ka--anafleiding ontstaat, die correspondeert met de verhouding tusschen een ander grondwoord en den dáárvan afgeleiden ka--an-vorm, welke beide laatste als logisch intermediair wẹ̀l een actieven i-vorm naast zich hebben. Zoo zou men in ons geval b.v. kunnen denken aan invloed van het aan wayah semasiologisch verwante (h)urip, waarvan een afleiding ang(h)uripi voorkomt in de beteekenis van „weer in het leven brengen” = ,leven toevoegen aan”, „van nieuw, meer leven voorzien" > een mogelijk ka(h)uripan = ,van leven voorzien zijn”, „leven krijgen”, „nieuw, meer leven krijgen”. Men vergelijke hiermee de opmerkingen van van der Tuuk, ,Tobasche Spraakkunst” (Amsterdam 1867), tweede stuk, p. 167. Maar al mag men deze mogelijkheid, waarbij de Wilde's hypothese niet uitgesloten zou zijn, niet verwerpen, men mag haar toch ook nooit als meer dan een mogelijkhcid beschouwen, omdat zich de aard van de bij uitstek onlogische analogiewerking verzet tegen de argumentatie, waarmee men de mogelijkheid tot zekerheid zou kunnen maken; door dit te negeeren heeft dus de Wilde in elk geval de fout gemaakt van veel positiever te zijn dan hem vrijstaat. - Overigens zij nog opgemerkt, dat Gonda's opvatting aan waarde wint, wanneer een ka--an-afleiding van wayah (baya) $=$,,jeugdige levenskracht" in den zin van ,van jeugdige levenskracht voorzien” mogelijk zou blijken, aangezien de beide bezwaren, die in noot 25 geformuleerd zijn, dan zouden komen te vervallen. De vraag is nu maar, of het gelukken zal voor het Javaansch de noodige gevallen te verzamelen, waarmee men de hypothese van ka--an = ,voorzien van" aannemelijk zou dienen te maken; voorloopig veroorloof $\mathrm{ik} \mathrm{mij} \mathrm{tegenover} \mathrm{deze} \mathrm{theorie} \mathrm{zeer} \mathrm{sceptisch} \mathrm{te} \mathrm{blijven}$ staan. - Zie ook de volgende noot.

28) H. N. Kiliaan, „Javaansche Spraakkunst” ('s-Gravenhage 1919), zou in $\S 103$, eerste alinea, suggesties in die richting kunnen bevatten, maar m.i. is de aldaar gegeven uiteenzetting voor bestrijding vatbaar.

29) H. Kern is in zijn .,Bijdragen tot de Spraakkunst van het Oudjavaansch” blijkbaar niet aan de bespreking van de ka--an-vormen toegekomen.

${ }^{30}$ ) Dat is b.v. het geval met het Nieuw-Javaansche kengĕtan, ,zich herinneren”, dat vermoedelijk via * kengětan als substantief, ,herinnering”, ontstaan is en dat men dus desnoods als ,van herinnering voorzien”, ,herinneringsvermogen hebbend", kan opvatten. Gericke-Roorda geeft voor de beteekenissen „,herinnering”, „,geheugen”, „bewustzijn”, de vormen kaelingan en kaengětan, terwijl het KBW. en Juynboll's Woordenlijst het ka--an-substantief in het ge- 
heel niet vermelden; met het sterretje heb ik dus willen aanduiden, dat kengĕtan als substantief voor het Javaansch niet als in gebruik zijnde vorm in de litteratuur is aangetroffen. Vermoedelijk is echter de vorm kaelingan resp. kaengětan secundair, daar het oude grondwoord niet eling, doch iling (resp. niet engět, doch ingět) is en er blijkens den vorm van het adjectief, engět, uit a- plus ingět, een vorm kengětan verwacht had mogen worden. Het Soendaasch heeft, in adjectivische beteekenis, eveneens kaelingan, doch naast een zeldzamer voorkomenden vorm kelingan, hetgeen het vermoeden steunt, dat kelingan de in onbruik geraakte oudere vorm is.

Daar Gericke-Roorda kelingan en kengětan geeft onmiddellijk na ngelingi, ngengĕti (I, 129b) en vóór ngelingake, ngengětakěn, en door deze rangschikking wellicht samenhang tusschen ngelingi (resp. ngengěti) en kelingan (resp. kengětan) suggereert, is het misschien goed nog eens uitdrukkelijk te constateeren, dat kelingan (kengětan) normaliter niet het passief van ngelingi (ngengĕti) kan zijn, daar beide vormen hetzelfde subject hebben.

Wat dit „normaliter" betreft: ik heb mij wel eens afgevraagd, of kelingan (kengětan) misschien ook verklaard zou kunnen worden als een geval van verschuiving van subject. Zooals men weet, komt het een enkelen keer voor, niet alleen in het Javaansch, maar ook in andere Indonesische talen, dat grondwoorden dubbelzijdig zijn, d.w.z. dat zij als praedicaatswoord gebruikt kunnen worden van een subject met betrekking tot een object, maar omgekeerd ook van dat object (dat dan natuurlijk subject wordt) met betrekking tot het subject van zoo even (dat dan natuurlijk object wordt). Zulk een dubbelzijdig woord is b.v. wěnang, dat, wanneer men het van een persoon gebruikt, de beteekenis heeft van ,(iets) in zijn bereik hebben liggen” $>$,over iets macht, zeggenschap hebben”, „,bereiken”, ,,iets kunnen”, ,iets of iemand aankunnen”, terwijl het, wanneer het van een zaak gezegd wordt, ,in iemands bereik liggen", „kunnen”, „mogelijk zijn”, ,geoorloofd zijn”, beteekent. Met het oog op zulke woorden nu heb ik een Nieuw-Javaanschen vorm kĕduga wel verklaard als primair - n.l. naast een actieven vorm anduga = „peilen", „trachten te bereiken”, „begrijpen” - te beteekenen „bereikt worden”, n.1. door een niet als actief voorgesteld wordend logisch subject, en dus ,in iemands bereik liggen”, en als eerst secundair te zijn gaan beteekenen ,(iets) in zijn bereik hebben liggen”, „tot iets in staat zijn”, ,iets op zich kunnen nemen”, „,bereid tot iets”, „tevreden met iets” enz., in welk geval er dus een verschuiving van het subject zou hebben plaats gevonden zóódanig, dat wat eerst logisch subject was, tot grammaticaal subject is geworden en wat eerst grammaticaal subject was, geworden is tot schijnbaar object; op dezelfde wijze een vorm als kĕrungu, primair ,gehoord worden”, n.l. door iemand, die er niet actief naar streeft iets te hooren, dus $>$,ter oore komen (van iemand)", en secundair ,iets te hooren krijgen”, ,iets bij geruchte vernemen”, met dezelfde verschuivingen als zoo even. Zoo zou men zich natuurlijk ook kunnen voorstellen, dat zulk een verschuiving bij kelingan had plaats gevonden, waardoor uit een primair ,in iemands herinnering liggen" - als passief van ngelingi = ,zich iets herinneren”, met een normalen overgang van het object van den actieven vorm, = de zaak, die men zich herinnert, tot subject van den passieven vorm - een secundaire beteekenis ,iets in zijn herinnering hebben liggen" $>$,zich iets herinneren" zou zijn ontstaan; in dat geval toch zou het huidige kelingan op deze wijze bevredigend zijn verklaard en zou men niet zijn toevlucht behoeven te nemen tot afleiding uit een hypothetisch a-kelingan, den adjectief-vorm naast een verondersteld substantief kelingan = ,herimneringsvermogen".

In den laatsten tijd echter hel ik er toe over in kĕduga het accidenteele passief van een in onbruik geraakten vorm ndugakake als causativum van nduga, dus 
,iemand (iets) doen bereiken”, ,iemand in staat stellen tot", te zien; dan zou kĕduga via ,in staat gesteld worden tot (iets)” (door een niet actief optredend logisch subject) zijn gaan beteekenen „tot iets in staat zijn”, ,zich tot iets in staat voelen", „tot iets bereid zijn" enz., met een normalen overgang van het object van den actieven causatieven vorm tot subject van den passieven causatieven vorm. Men bedenke daarbij, dat het eerste object van den causatieven vorm in zeer veel gevallen het subject van den grondvorm, waarvan men uitgaat, is, zoodat het subject van dien grondvorm - in ons geval nduga - in zulke gevallen identiek is met het subject van de passieve causatieve vormen; verder, dat het causatieve in. een vorm als kěduga door het niet-actief zijn van het logische subject, waaraan de veroorzaking wordt toegeschreven, uiteraard voor een groot deel verdwijnt, zoodat het practische resultaat is een in hoofdzaak gelijke beteekenis van den grondvorm en van het accidenteele passief van het causativum, al kan het spraakgebruik natuurlijk tusschen de beide vormen een verschil scheppen. Op analoge wijze zou ik het krungu van een zinnetje als aku wis krungu kabar iku, „ik heb dat bericht gehoord”, willen opvatten als accidenteel passief hij ngrungoni, ,iemand iets mededeelen", met den persoon, aan wien men mededeelt als eerste object en derhalve ook als subject van den passieven vorm. Indien deze laatste verklaring van vormen als kĕduga en krungu - waaraan nog enkele andere woorden toe te voegen zouden zijn - juist mocht zijn, dan zou daarmee vermoedelijk het verschijnsel der dubbelzijdigheid teruggebracht zijn tot de gevallen, waarin de twee op de hierboven beschreven wijze verwante beteekenissen aan het grondwoord eigen zijn, met uitsluiting dus van min of meer toevallige tweezijdigheid in de beteekenissen der afleidingen, en speciaal van het accidenteele passief. Dan zou er voor kelingan (kengětan) geen aanleiding zijn om te denken aan een beteekenisverschuiving van ,in iemands herinnering liggen” tot ,iets in zijn herinnering hebben liggen" en zou de hypothese, dat Nieuw-Javaansch kelingan $=$,zich herinneren” zijn oorsprong dankt aan een hypothetischen vorm akelingan = „herinneringsvermogen hebben”, de eenige oplossing vormen. In het andere geval zou het voorbeeld van deze noot niet gelukkig gekozen zijn en zou er voor het leveren van het bewijs, dat ka--an-adjectieven uit ka--ansubstantieven kunnen ontstaan, met eventueele praefigeering van a- in een vroeger stadium van de taal, een ander voorbeeld gezocht moeten worden.

Deze uitweiding dient om een keer te meer te demonstreeren, op hoeveel onzekerheid men telkens en telkens weer stuit bij het zoeken naar verklaringen voor verschijnselen, die wij in elken Javaanschen zin, of hij uit een Oud- of een Nieuw-Javaanschen tekst gelicht is, en ook wanneer de inhoud er van volkomen duidelijk is, ontmoeten, en hoe voorzichtig men moet zijn met apodictische oplossingen!

31) Het is hier wellicht de plaats om ter aanvulling van mijn artikel in deel 85 van de Bijdragen op te merken, dat men zich, wanneer men kab(h)ayan van bhaya afgeleid acht, de adjectivische beteekenis "magisch-gevaarlijk" moet voorstellen als ontstaan uit de substantivische beteekenis „magisch gevaar", die primair zou zijn (aldaar, p. 471). In een geval als dit zou het adjectief kab(h)ayan direct uit het gelijkluidende substantief ontstaan kunnen zijn, dus zonder een intermediairen vorm akab(h)ayan, daar de begripsinhouden van „gevaar" en ,gevaarlijk" zoo dicht bij elkaar liggen, dat de overgang van het eene tot het andere onmiddellijk kan geschieden.

32) Loco citato, p. 236 boven.

33) Wij vinden in het Javaansch nog een enkel geval meer, dat de -h bewaard is gebleven, b.v. manah, Sanskṛt manas. 
34) Gonda's verklaring van het woord pantěnb(h)aya (Bijdragen, deel 90, p. $162-163)$, volgens welke het tweede stuk van dit woord, baya, = Maleisch baya (en Menangkabausch bayò) zou zijn, is, daar zij het eerste stuk van het woord niet bevredigend verklaart, voorshands zelf zóó hypothetisch, dat men haar moeilijk kan aanvoeren als een argument vóór A.'s hypothese.

35) „Zugegeben, dass der Alten [te weten: de oude vrouw der Maleische verhalen, Nenek Këbayan] als Märchenfigur auch übernatürliche Kräfte innewohnen, halte ich die Ableitıng dennoch nicht für richtig", zegt A. op p. 237 van zijn opstel. In alle bescheidenheid zij echter opgemerkt, dat „dennoch" geen argument is. Ik meen niet ver van de waarheid te zijn, wanneer ik aanneem, dat A.'s voornaamste argument tegen de afleiding van bhaya is, dat een woord slechts van één grondwoord te gelijk afgeleid kan zijn, en dat kabayan dus niet meer als uit bhaya ontstaan te verklaren kan zijn, wanneer eenmaal bewezen is, dat het een afleiding van het aan wayah gelijke baya is. Voor mij, die A.'s verdediging van zijn stelling te zwak acht, heeft echter uiteraard ook dit argument geen waarde.

Intusschen zou ik nogmaals, zoowel aan het adres van Dr. Aichele naar aanleiding van de hierboven geciteerde opmerking en het daarin gelegde verband tusschen den aard van Nenek Kĕbayan en de etymologie van het woord kabayan, als aan het adres van de Wilde, die ,aan een dorpsbode (n)iets vrouwelijks of gevaarlijks" ziet en daarom voor het woord kabayan noch aan een afleiding van bhaya = ,gevaar", noch aan een afleiding van bay = „vrouw" wil gelooven, de opmerking willen maken, dat woordetymologie en begripsinhoud twee geheel verschillende zaken zijn (vg1. Bijdragen, deel 85, p. 473, en het daar aangehaalde citaat uit de dissertatie van Pigeaud). Voorbeelden van een zeer ver gaande divergentie van die twee zijn er uit elke taal aan te voeren.

Van de juistheid van Mevr. Coster's opmerking, dat de Oude-Vrouw-figuur zich principiëel van de panakawan's en de paranjai's onderscheidt en dat er dus geen mythologische verwantschap bestaan kan tusschen de Nenek Kĕbayan der Maleische verhalen en de Ken Bayan der Javaansche of an de Javaansche litteratuur ontleende verhalen - laatstgenoemde wordt, naar mij later gebleken is, intusschen vaak $\mathrm{Ka}$ Bayan genoemd!! - , houd ik mij gaarne overtuigd, en in mijn vorige artikel dienen dan de woorden „,van verwanten aard en" op p. 475 , beneden, te vervallen. Dat ik echter zelfs bij een nog veel grooter verschil in mythologische waarde de mogelijkheid van etymologische verwantschap meen te moeten handhaven, zal uit het voorgaande voldoende duidelijk geworden zijn.

36) H. C. Klinkert, „Nieuw Maleisch-Nederlandsch Woordenboek” (Leiden 1916), p. $139 \mathrm{~b}$.

37) J. L. van der Toorn, ,Minangkabausch-Maleisch-Nederlandsch Woordenboek" ('s-Gravenhage 1891), p. 50b.

38) In dat geval zouden baya en wayah natuurlijk niet meer als doubletten te beschouwen zijn, al zou - hetgeen de Sanskrtisten hebben uit te maken er ook een samenhang tusschen de beide woorden in het Sanskṛt bestaan. Naar het schijnt, heeft echter ook Sanskrtt wayas soms de ruimere beteekenis van „Stufe”, ,Art überh.”, „Sorte” (Petersb. Wrdb., als mogelijkheid); mocht dat zoo zijn, dan zou de kans, dat Maleisch baya en Menangkabausch bayò met Sanskṛt wayā in plaats van met wayas samenhangen, natuurlijk geringer worden.

39) Voor alle zekerheid zij opgemerkt, dat het wayah, dat KBW. s. v. wayah opgeeft voor Rām. 2, 1, 7 (= 3, 7, a van de editie-Kern), in den Balischen commentaar thuis hoort en dat de Javaansche tekst er kaki heeft; men zou 
anders geneigd zijn te denken, dat van der Tuuk's woordenboek een bewijsplaats voor Oud-Javaansch wayah in den zin van ,grootvader" leverde. - In verband met den samenhang tusschen de beteekenissen „leeftijd” en „grootvader” van het woord wayah waag ik het de vraag te stellen, of wellicht ook het Maleische woord ayah = „vader" op het Sanskṛt wayas of wayah teruggaat. Van der Tuuk merkt op (KBW., I, 343b, s. v. ayah II, en IV, 463b, s. v. yayah), dat het blijkens yayah ook in het Oud-Javaansch bestaan moet hebben; verder merkt hij op, dat het Oud-Javaansche woord yayah, dat doorgaans voor ,vader" gebruikt wordt, ook "moeder" schijnt te hebben kunnen beteekenen, hetgeen past bij de mededeeling van R. van Eck (,Eerste proeve van een BalineeschHollandsch Woordenboek", Utrecht 1876, p. 152), dat het Balische wayah eveneens zoowel den grootvader als de grootmoeder kan aanduiden. Voorts blijkt de huidige Javaansche spreektaal, naar de opgave van Gericke-Roorda (II, 66b), het woord ayah in het algemeen te gebruiken als nevenvorm voor wayah. Daar de begin-w in het Javaansch herhaaldelijk afgestooten wordt, zouden wij kunnen gissen, dat ayah zich in het Javaansch als nevenvorm van wayah gevormd heeft en dat het in het Oud-Javaansch door verdubbeling tot yayah geworden is, terwijl het in de Nieuw-Javaansche spreektaal benevens in het Maleisch, waarin het dan uit het Javaansch overgenomen is, in den vorm ayah is blijven voortbestaan, zij het in verschillende beteekenissen.

40) Op deze mogelijkheid wijst ook Gonda met zijn opmerking: „Misschien rechtstreeks verband: Skt. ,,jeugdige leeftijd” - Soend. Uilenspiegel?? (Vgl. $J a v$. wajah $=$ poetoc?)" (cursiveering van mij, B.).

In dat geval zouden wij dus moeten aannemen, dat de beteekenissen ,grootvader" (resp. „grootmoeder”) en „vader" (resp. „mueder”) aan den eenen kant en die van "kleinzoon" aan den anderen kant onafhankelijk van elkaar uit wayah ontstaan zijn, het laatste uit wayah's beteekenis ,,jeugdige leeftijd", eerstgenoemde beteekenissen uit een te voren ontwikkelde praegnante beteekenis „leeftijd” = ,hooge leeftijd".

41) Intusschen heb ik nog geen materiaal onder oogen gehad, dat ondubbelzinnige aanwijzingen vóór de afleiding van wayah opleverde. Ten aanzien van de Tantri-plaats, waarop Mevr. Dr. Coster-Wijsman attent maakt (Bijdragen, deel 90, p. 141), zou ik willen opmerken, dat zij juist niet voor Aichele's hypothese pleit, aangezien een kabayan in de beteekenis „oud" na tuha-tuha geheel overbodig zou zijn, en niet is aan te nemen, dat het, als vreemd woord, dienen zou ter verklaring van een heel alledaagsch inheemsch woord als tuhatuha. De beteekenis ,eerbiedwaardig”, ,aanzienlijk”, die van bhaya af te leiden zou zijn, zou hier bovendien uitstekend passen. Ook zij in verband hiermee geconstateerd, dat de Tantri blijkens een uitdrukking wayah tuha $=$ „oud van leeftijd" (prozatekst, ed. Hooykaas, p. 28, 19) wayah gebruikt in den neutralen zin van "leeftijd" en niet voor „ouderdom", daar in dat geval de toevoeging van tuha niet noodig zou geweest zijn.

Ten aanzien van de Tjirěbonsche bosschen, die men „kabayan” noemt, helt Mevr. Coster, zooals blijkens de vertaling ,geheiligde of gezegende wouden” te voren vermoedelijk reeds Roorda van Eysinga, over tot de meening, dat dit kabayan wel van bhaya zal zijn af te leiden. Men zou deze opvatting kunnen steunen met een verwijzing naar een plaats als Adiparwa 142, 1-2: mahābhaya tan sinipi iking alas pinaranta, en de ongeveer gelijkluidende passage 141, 12 (even verder van Hidimba: pinakabhaya ning alas!). Wel zou men daartegenover weer kunnen wijzen op het alas wayah, dat KBW. s. v. wayah met wana gahana = „diep, dicht, ondoordringbaar woud" weergeeft en waarvan van der Tuuk (aldaar s. v. daha, II, 384b) opmerkt, dat het slaat op nog nooit betreden bosch, doch het komt mij voor, dat dit bezwaar tegen de hier besproken en 
ook door mij bij voorkeur aanvaarde opvatting toch niet al te belangrijk geacht kan worden, want dat er volstrekt geen samenhang tusschen het wayah en het kabayan van de uitdrukkingen alas wayah en wana kabayan behoeft te bestaan; het laatste toch is gereedelijk te verklaren uit een grondwoord bhaya, terwijl het eerste in den zin van ,oud bosch" eveneens gemakkelijk te begrijpen is, daar op Java en op Bali de bosschen, die sinds menschenheugenis bestaan, uiteraard ondoordringbaar zijn, in tegenstelling tot nieuwen aanplant. Dat oud $=$ ondoordringbaar bosch tevens geheimzinnig is en daardoor den indruk wekt van gevaarlijk of magisch-gevaarlijk te zijn, laat zich ook hooren, maar dat behoeft nog geenszins een nadere verwantschap van dit wayah en dit kabayan in te sluiten; het naast elkaar voorkomen dezer beide woorden bij eenzelfde substantief behoeft niet meer dan coincidentie te zijn.

Met betrekking tot het Zuid-Sumatraansche kĕbayan, waarop de heer Helfrich Mevr. Coster en Dr. van Hinloopen Labberton (vgl. noot 4) mij opmerkzaam maakte, houdt zich Mevr. Coster er van overtuigd, dat het op bay, běbay, „vrouw”, „vrouwelijk”, teruggaat (Bijdragen, deel 90, p. 142). Zoo zeker als zij van de juistheid dezer afleiding is, ben ik niet. Wordt niet de opvatting verdedigd, dat de vrouw in de uitingen van haar sexueele leven bij primitieve volkeren als magisch-gevaarlijk geldt en dat ook uit de verandering van een in het kraambed gestorven vrouw in een pontianak de wezenlijke gelijkheid dier twee voor het volksgeloof te concludeeren valt? Mocht dat juist zijn, dan lijkt het feit, dat men de jong-gehuwde vooral bij of kort na haar overgang tot dezen staat kěbayan = "magisch-gevaarlijk" noemt, toch niet zoo heel vreemd. Intusschen wil ik, trouw aan mijn van het begin af aan ingenomen standpunt, dat men bij den huidigen stand van onze kennis van Indonesische talen beter doet met het overwegen van mogelijkheden dan met het doen van apodictische uitspraken, allerminst de mogelijkheid uitschakelen, dat het kěbayan in kwestie inderdaad met bay samenhangt. Zelfs geloof ik, dat het niet eens zoo moeilijk zou zijn samenhang met een verondersteld kabayan $=$,leeftijd" te verdedigen - „den leeftijd (praegnant: den geschikten leeftijd) bereikt hebben”, „oud genoeg zijn om te trouwen” - , al ligt deze afleiding ook het minst voor de hand en is zij minder naar mijn smak. Gebrek aan gegevens omtrent de herkomst van het Zuid-Sumatraansche kĕbayan maakt het in dit geval wel bijzonder moeilijk om voorkeur uit te spreken.

Het kabayan van de Agastyaparwa-plaats, waarnaar Gonda verwijst (Bijdragen, deel 90, p. 163): strī kabayan ikang lěwas ring rah [het KBW. geeft s. v. lěwas voor Adig. $60 \mathrm{~b}$ : lĕwas ring rat!], kàn als een aanwijzing voor kabayan's afleiding van wayah beschouwd worden, maar behoeft het toch niet te zijn, èn omdat ouderdom iemand vanzelf recht op het ontzag van anderen geeft, zoodat dit strī kabayan kan zijn ,een met eerbied behandelde vrouw”, „een vrouw van aanzien”, èn omdat kabayan slechts secundair „oud” kan zijn, zooals reeds is betoogd. Het op kabayan volgende lěwas, dat o.a. „oud” kan beteekenen, bewijst dus niet zoo heel veel.

Ten slotte vestig ik nog de aandacht op het feit, dat Gericke-Roorda s.v. kĕbayan den vorm ngĕbayani aan nuwani van het grondwoord tuwa = "oud" gelijkstelt, en dat het KBW. s. v. bhaya den vorm kabayan-kabayan geeft in den zin van „zeer gevaarlijk v. e. ziekte”. Het eerste steunt Aichele's hypothese, ofschoon tuwa hier klaarblijkelijk = „chef” en nuwani dus „chef zijn over" is, en de beteekenis ,chef" voor kabayan aanvaard kan worden ook zonder dat men zich voor afleiding van wayah behoeft uit te spreken. Het tweede biedt daarentegen weer eenigen steun aan mijn pleidooi voor bhaya.

Men ziet, dat uit dit materiaal, dat voor een deel den laatsten tijd bekend gemaakt is, toch moeilijk een doorslaggevend argument ten behoeve van deze 
of gene meening te halen is, en dat het resultaat van het onderzoek is, dat de onzekerheid, die ik in deel 85 van deze Bijdragen constateerde, onverminderd voortbestaat.

42) Zie hierboven p. 605 , p. 612 en noot 6.

43) Vgl. noot 4 en noot 41 , derde alinea.

\section{ADDENDA.}

Aan noot 13 op p. 623 is het volgende toe te voegen:

Het Oud-Javaansch verschilt in zooverre van het huidige Javaansch, dat daar ratu ook optreedt in adjectivische afleidingen, waarin een praefix, makab.v., de functie vervult van het inleidende adjectief, koppelwerkwoord, zoo men wil, van het huidige Javaansch (dadi, dados, juměněng). De vraag, of ratu zelf in het Oud-Javaansch als praedicaatswoord kan optreden in den zin van „koning zijn”, valt niet met zekerheid te beantwoorden. Juynboll, Wrdl., geeft ratu zelf niet als zoodanig op, doch wel een irrealiteitsvorm ratwa, en wel voor Rt. (= Ratnawijaya) 3, 2 (onvindbaar; wel te lezen Rāmāyaṇa 3, 2, aangezien aldaar een ratwa voorkomt), Arjunawiwāha 29,2, Rāmãyaṇa 3, 3 en Ādiparwa 97; bovendien bestaat de mogelijkheid, dat het piratwa, dat Juynboll opgeeft voor Rāmāyaṇa 3, 47, in pi en ratwa te splitsen is. In een der handschriften

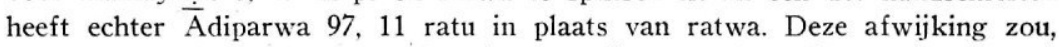
in het voordeel van A.'s opvatting, kunnen wijzen op de gelijkwaardigheid van ratu en ratwa, afgezien van de beteekenis van het suffix -a. Intusschen bestaat de mogelijkheid, dat dit ratwa niet is te beschouwen als irrealiteitsvorm van ratu, doch van rinatu, ,als koning beschouwd, tot koning uitgeroepen, als koning erkend worden", een irrealiteitsvorm, die gekenmerkt zou worden door het wegvallen van het infix -in- van den realiteitsvorm en die tot rinatu zou staan als ratwakěna (Ädiparwa 135) tot rinatwakěn (A diparwa 98). Weliswaar zou deze irrealiteitsvorm dan verschillen van de groote massa der passieve irrealiteitsvormen bij genasaleerde grondwoorden zonder -i of -akěn, die immers bestaan uit het ongenasaleerde grondwoord plus het suffix -n, -ěn of -něn (Kern, V. G., 8, p. 230), doch blijkens ucapa en wuwusa (Kern, ibidem) komt de vorming met -a voor en staat dus voor ratwa deze verklaring vrij. Mocht ratwa bij rinatu behooren, dan zouden de door Juynboll gegeven loci natuurlijk geen enkele aanwijzing bevatten voor het voorkomen van ratu als praedicaatswoord; het ratu van de varia lectio van Adiparwa 97, 11 zou dan als waardeloos te beschouwen zijn.

Welk van de twee mogelijkheden de voorkeur verdient, zal alleen uit te maken zijn door een speciaal daarop gericht onderzoek. Mocht het het geval zijn, dat de vorm ratun of ratuněn als passieve irrealiteitsvorm van angratu gevonden werd, of mocht men andere substantieven, bij voorkeur titelnamen, vinden, die zonder een praefix kumnen optreden als praedicaatswoord, dan zou daarmee een sterke steun gevonden zijn voor A.'s opvatting: mocht het onderzoek daarentegen negatief verloopen, dan zou ik dat als argument kunnen aanvoeren tegen $\mathrm{A}$. Bij zulk een onderzoek zal men echter tevens te overwegen hebben, dat er in het geval van het alawas ratu van onze Wirāțaparwa-plaats geen subject is uitgedrukt en dat alawas aan ratu voorafgaat, waardoor het „verbale” karakter van ratu, gesteld dat alawas ratu zou beteekenen ,ik ben reeds lang koning”, veel meer in het oog zou springen dan b.v. in een zin „Rāma was reeds lang koning van Ayodhyā".

Voorts schijnt men voor sommige der door Juynboll opgegeven plaatsen de. 
vraag onder het oog te moeten zien, of ratwa geen appositie kan zijn bij een voorafgaand persoonlijk voornaamwoord sira, in welk geval het niet als adjectief en praedicaatswoord, maar als substantief zou optreden. Deze mogelijkheid lijkt mij niet uitgesloten voor een voorbeeld als sang sun:ādhya sira ratwa, dan te vertalen met „die zichzelf als a.s. koning doodverft” (KBW., s.v. ratu), doch ik geef dadelijk toe, dat zij voor het meerendeel der opgegeven plaatsen wèl uitgesloten lijkt.

Intusschen, mocht A. al kans zien te bewijzen, dat ratu als praedicaatswoord kan optreden - voorloopig lijkt mij dit nog weinig waarschijnlijk -, dan zou hij nog slechts voor de helft klaar zijn, aangezien hij verder het alawas ratu in den zin van ,ik ben reeds lang koning” in harmonie zou moeten kunnen brengen met het er op volgende ngaran ing ulun, dat hij in zijn vertaling schijnt te negeeren, maar dat juist een sterken steun geeft aan de opvatting, dat alawas ratu een naam of een titel is en geen mededeeling van een feit.

Aan noot 23 op p. 626 is het volgende toe te voegen:

$\mathrm{Na}$ het afsluiten van den tekst van mijn opstel werd mijn aandacht gevestigd op het kalěpasĕn van Arjunawiwāha 5,6 , d en 5, 10, d benevens van Rāmāyaṇa 25, 22. Dit steunt de opvatting, dat er in het Oud-Javaansch ook ka--ěn-substantieven geweest zijn. Voorts heb ik nog nagezien, of de metriek omtrent den oorsprong van de $\mathrm{u}$ en de $\mathrm{i}$ van woorden als kaprabhun en kadadin eenig licht kon verschaffen. Indien deze $\mathrm{i}$ en $\mathrm{u}$ metrisch kort zouden geweest zịin, zou dit eenigen steun gegeven hebben aan de opvatting, dat zij uit samentrekking van i resp. u met een pěpět ontstaan zijn. Dit onderzoek heeft echter een negatief resultaat gehad, daar b.v. de u van karatun in Rāmāyaṇa 19, 63, b lang is, hoewel er slechts één consonant op volgt. Uiteraard bewijst dit niets voor de opvatting, dat hier samentrekking van u en a heeft plaats gevonden, daar ook samentrekking van $\mathrm{u}$ en pĕpĕt een lange u kan opleveren! 